\title{
China's Economic Growth 1978-2025: What We Know Today about China's Economic Growth Tomorrow
}

Views of the future China vary widely. While some believe that the collapse of China is inevitable, others see the emergence of a new economic superpower that increasingly poses a threat to the U.S. This paper examines the economic growth prospects of China over the next two decades. Extrapolating past real GDP growth rates into the future, the size of the Chinese economy surpasses that of the U.S. in purchasing power terms around 2010. Such extrapolations can be supported by standard growth patterns identified in economic development and trade theories (structural change, catching up, and factor price equalization). They can also be supported by an explanation of China's past GDP growth through growth of various labor variables, with a subsequent derivation of future GDP growth based on reliable information about future labor quantity and quality. China's demographic changes and economic growth have a number of implications for China and the world.

JEL codes: O1 (O10, O11), O4 (O40, O47), O53, J11, O3, I21

Keywords: economic growth, growth accounting, growth forecasts, development theories, human capital formation, education (all: China)

\author{
Carsten A. Holz \\ Social Science Division \\ Hong Kong University of Science \& Technology \\ Clear Water Bay \\ Kowloon \\ Hong Kong \\ E-mail: socholz@ust.hk \\ Tel/Fax: +852 2719-8557
}

26 December 2006

(Incorporates minor revisions of the 3 July 2005 and 2 November 2005 versions, and extends the conclusions/ implications. Updates all sections except section 4 to include data for the most recent years and, in the case of China, incorporates the revisions following the 2004 economic census. Section 4 will be updated once the $20051 \%$ population sample survey data become available.)

The work described in this paper was supported by a grant from the Research Grants Council of Hong Kong (Project HKUST 6423/05H). 


\section{Introduction}

The rapid economic growth of China since the beginning of the economic reforms in 1978 has captured the imagination of Western commentators and researchers. The responses range from outright pessimism about China's future to fear of a strong China. Lester Brown (1995) wonders who will feed China. Gordon Chang (2000) announces the coming collapse of China. Callum Henderson (1999) sees China as on the "brink," while Ross Terrill (2003) writes of the "illusory nature of the market in most of the Chinese economy" and that "a crash looms because the Leninist core of the regime is unchanged from Mao's construction of it in Yan'an six decades ago" (pp. 329, 313). Nicholas Lardy (1998) stresses the large economic problems and the unprecedented potential for social unrest due to ever more indebted state-owned enterprises, the extent of nonperforming loans, and a decline in government revenue.

At the other end of the range are those who project a strong China. Geoffrey Murray (1998) describes China as the next superpower. A number of authors view an all-powerful China as a threat (Bill Gertz, 2000, or Edward Timperlake and William Triplett II, 2002). ${ }^{1}$ News items imploring the "devastation Chinese competitors are inflicting on U.S. industries, from kitchenware and car tires to electronic circuit boards" and the "futility of trying to match the China price" have become common fare. ${ }^{2}$

What is undeniable is China's rapid economic growth over the past 27 years, from the beginning of economic reforms in 1978 through 2005, of, measured in gross domestic product (GDP), on average 9.6\% per year. In economic size, China in 2005 was surpassed only by the U.S., Japan, and Germany. ${ }^{3}$ Its share in global growth 1995-2002 has been estimated at $25 \%$, compared to $20 \%$ for the U.S. ${ }^{4}$

While China's economic growth has received much attention in the popular literature, China researchers, when it comes to economic growth, tend to focus on narrow topics, measuring total factor productivity growth in enterprises in different ownership forms or investigating the growth prospects of individual industries or firms. For example, Douglas Allen (2002) documents the transformation in four industries in China and predicts the imminent emergence of world-class Chinese brands. Ming Zeng and Peter Williamson (2003) 
examine the international growth prospects of Chinese firms (positive). Colin Carter and Scott Rozelle (2001) ask if China will become a major force in world food markets (yes, if structural transformation occurs).

A number of studies try to explain China's past economic growth. Much of the transition literature explains past reform successes - usually, if only implicitly, measured as economic growth - through institutional changes (for example, Qian Yingyi, 2000, 2003, or Wing Thye Woo, 1994, 1999). Justin Lin, Cai Fang, and Li Zhou (2003) explain China's reform success with adoption of a "comparative-advantage following strategy," allowing full play to China's plentiful endowment with labor. Others analyze China's past economic growth within the aggregate production function framework (Wang Yan and Yao Yudong, 2003; Wu Yanrui, 2004, Alwyn Young, 2003). The aggregate production function framework is also occasionally extended into the future. Gregory Chow and Kui-Wai Li (2002) estimate an economy-wide, aggregate production function for the years 1952-98 and obtain GDP values for the years through 2010 by extending variations of past factor input growth rates into the future; Gregory Chow (2002) further includes an estimate of year 2020 GDP. A 1997 World Bank policy analysis of current economic issues is supplemented by an estimate of China's GDP in 2020 based on a closed-economy model. A systematic study of future economic growth in China that makes full use of the hard facts already available today, however, is still lacking. 5

Answers to the question of what we know today about the economic size of China ten or twenty years from now are relevant not only for the popular discourse on the new superpower and for China threat theorists and military strategists, but also for economists. For example, conventional economic wisdom holds that free trade benefits, by the laws of comparative advantage, all countries in the long run. Thus, a growing China, and growing trade between China and the U.S., benefits the U.S. But as Paul Samuelson (2004) within the framework of standard trade theory shows, a productivity gain in one country in the production of the good in which the other country previously had a comparative advantage may, in fact, lead to a permanent loss in per capita real income in the other country; references to China, as the country with a productivity gain, abound. 
This paper examines China's future economic growth in three steps. First, it conducts a straightforward extrapolation of a stable, past growth trend into the future. A number of scenarios are played through in a comparison with the U.S. But extrapolation is not a particularly convincing research tool. Why should past trends continue into the future?

One argument why past economic growth may continue into the future is that China's economic growth matches standard growth patterns identified by theories of economic development and trade. These are structural change, catching up, and factor price equalization. China's past economic growth fits well with all three. Furthermore, China's reform period growth, within these three analytical frameworks, matches those of Japan, Korea, and Taiwan at an earlier stage of their development. Obviously, these four countries differ, as do the domestic and international circumstances under which they experienced a particular stage of development. But the differences need not be systematic with respect to the impact on the dependent variable economic growth. These growth patterns may well apply to China in the future, just as they already have to Japan, Korea, and Taiwan in the past.

A second argument why past economic growth may continue into the future is based on the decomposition of GDP growth, following the income approach to the calculation of GDP, into growth of labor and other variables (a simplified version relies on the definition of the labor share, with the labor share constant over time). What we know today about the future is the number of laborers and their education level. We know with near-certainty the size of China's working age population through 2015 , and can project with high reliability for several years after. In as far as gains in high school and university enrollment, most of them very recent, are unlikely to be reversed, a bottom line scenario on the quality of China's future laborers can be developed. Future GDP growth can then be re-composed using solely the hard facts about the future quantity and quality of labor available today.

A key result of the decomposition of GDP growth is the importance of future labor quality in driving continued economic growth in China. China's demographics means, for example, that for every "genius" in the U.S., China potentially has four. If talent is randomly distributed in the world population and if China's education system is able to identify the brightest students, then China has a larger pool of talent to draw from than any other country 
in the world. If growth and innovation depend on the agglomeration of talent (geographically, nationally, culturally, or linguistically), then China is in an excellent position to continue to grow and innovate. The recent explosion in tertiary level education in China may yet supply the productivity gains that Paul Samuelson identifies as potential causal factors for a permanent loss through trade in U.S. per capita real income.

Projections cannot predict the future with certainty. Potential complications range from a collapse of Chinese Communist Party rule to war in the Taiwan Straits; China researchers ruminate about such issues as the bad loan problem in China's banking system, loss-making state-owned enterprises, pilfered pension funds, local government budget deficits, rural-urban inequality, and environmental degradation. This paper works within these limitations. It does not attempt to provide an exhaustive list of complications, let alone examine the individual items, to quantify their potential impact, and to attribute a likelihood to their occurrence. It predicts China's future economic growth under the assumption that current and future problems continue to be resolved as they arise, and that events of catastrophic dimensions do not occur. ${ }^{6}$

\section{Extrapolation of Past Growth into the Future}

China's year 2005 nominal GDP of 18.308 trillion RMB at the official average annual exchange rate of 8.1917 RMB per USD translates into USD 2.235 trillion, compared to year 2005 U.S. GDP of 12.456 trillion. $^{7}$ The U.S. economy in 2005 , thus, was almost six times larger than the Chinese economy. However, such a comparison neglects to take into account the differing price levels in the two countries. The Penn World Table 6.2 (PWT 6.2), which reports comparable GDP data in "international dollars," assumes that the general price level in the U.S. in 2004, the most recent year covered, was 3.86 times higher than the Chinese price level. Applying the 2004 price adjustment factor to the 2005 GDP data, the U.S. economy, today, in purchasing power terms, is only $43 \%$ larger than China's economy.

Table 1 asks in what year China's GDP will exceed that of the U.S., assuming that the past real growth rates continue into the future. The answers are obtained by, for China and the U.S. separately, applying the average annual real growth rate of the period 1978-2005- 
China's economic reforms started in 1978 - to year 2005 GDP, and then noting the year in which China's GDP value exceeds that of the U.S. ${ }^{8}$

In the first row in Table 1 it is assumed that the PWT 6.2 price adjustment factor of 3.86 (in 2004) continues to apply into the indefinite future. In this scenario, China's GDP begins to exceed that of the U.S., in purchasing power terms, in 2011. If one further incorporates a $3 \%$ annual appreciation of the RMB, reflecting the most recent exchange rate developments, the year when China's GDP exceeds that of the U.S., in purchasing power terms, moves further to the present, to 2009 (second row in Table 1).

The price adjustment factor in the case of China carries "substantial uncertainty" (Alan Heston, 2001, p. 1). The multiplicative factor of 3.86 could be considerably off in either direction. ${ }^{9}$ Assuming a price adjustment factor of 3, implies a cross-over year of 2015 or, with RMB appreciation, of 2012 (third and fourth row in Table 1). At the extreme, making no price adjustments whatsoever, the cross-over year moves twenty-five years into the future, to 2033, or, with RMB appreciation, to 2024 (fifth and sixth row in Table 1).

In terms of per capita GDP, the year when China surpasses the U.S. is twenty to fifty years into the future (see additional columns in Table 1). But what is far into the future for the average Chinese person moves closer to the present for the richer areas of China. One to two decades from now, coastal China (as defined in the notes to Table 1), accounting for $42 \%$ of China's population in 2005 and exceeding the U.S. population by $87 \%$, may well be as rich, per capita, as the average U.S. citizen. Focusing only on the five fastest-growing provinces in coastal China, with a joint population in 2000 that is $11 \%$ larger than the U.S. population, moves the cross-over year in per capita GDP a few years further to the present. In other words, by around 2020, a share of China's population that exceeds the size of the U.S. population could enjoy the same standard of living as the U.S.; in addition, China has a per capita poorer hinterland with roughly three times the population in the richer areas.

In these calculations, all variables were held constant except those explicitly allowed to vary. In particular, in the extrapolation of aggregate GDP, the use of an average annual past real growth rate reflects the product of the real GDP growth rate per capita and the population growth rate. In the short run, such as one decade, changes in the population growth rate are 
likely to be minor, but this may not hold in the long run. Similarly, the exchange rate was held constant in three scenarios, as was the price adjustment factor throughout (at the three different levels). The further into the future, the less valid are the assumptions. A more sophisticated approach would, furthermore, focus on the employed instead of the population. But none of these adjustments is likely to have a significant impact on the determination of cross-over years which are less than a decade away. ${ }^{10}$

Extrapolations do not constitute a reliable research tool. The following two sections substantiate the extrapolations.

\section{Development Theories and Asian Precedents}

Explanations of China's economic growth tend to focus on economic transition. The "success" of the reform process is explained by transition facts and strategies, where success is usually taken to imply economic growth (or a rise in living standards). For example, WingThye Woo (1994) lists as crucial the creation of non-state firms in every sector of the economy, a high savings rate, good initial conditions (such as a small extent of central planning, unemployment in the countryside that could be taken up by township and village enterprises, or a limited social security net), historical conditions, and the Chinese Diaspora. Qian Yingyi (2000, 2003) ascribes much of China's reform success to the unorthodox economic policy measures adopted by China's leadership; the key to China's economic growth was the unleashing of incentives and competition while making reform interestcompatible for those in power.

Yet these explanations of past economic reform successes (and thus economic growth) face the problem of lack of a counterfactual. Wing-Thye Woo offers cross-country comparisons, but the number of explanatory variables appears larger than the number of comparison countries. Qian Yingyi makes an in part historical argument, but offers no explicit time series evaluation that examines the status before and after a particular reform measure was implemented. These explanations, thus, are not as strong as one might wish them to be. ${ }^{11}$ 
If one claims that economic transition "in total" has caused China's past economic growth, then one could argue that key elements of transition have been in place since the early 1990s (price and domestic trade liberalization, the entry of private enterprises) and that therefore the gains from transition have already been exhausted. Consequently, economic growth should since have slowed, which it didn't, or it could slow any time soon. Alternatively, one could argue that past transition measures impact on economic growth over an extended period of time, or that transition is as yet incomplete, with further measures to go, in which cases the gains continue.

Growth patterns identified by economic theories of development and trade perhaps offer firmer ground. Economic transition could then be viewed as the removal of constraints that prevented well-known development patterns from unfolding. ${ }^{12}$ Furthermore, if China's reform period growth patterns match those exhibited by other countries at stages in their economic development similar to China's development level in the reform period, then China's future growth patterns may also match those of the other economies later. The argument has two foundations: one is a focus on standard growth patterns, the other is a cross-country comparison with countries with which a comparison is likely to be meaningful.

The growth patterns are structural change, catching up, and factor price equalization. ${ }^{13}$ These three patterns are not independent of each other, nor do they hold irrespective of the larger economic environment. They represent uni-causal explanations of economic growth that have the advantage that they do not rely on individual transition measures and that they have been identified by development economics and trade theory as of relevance. In as far as China is at the very early stages of these accepted development patterns, they suggest continued future economic growth.

The comparison countries are Japan, Korea, and Taiwan. These three countries are relevant for China only if the assumption of constant effect among the four countries is met: different countries do not differ systematically with respect to the impact of the explanatory variable (specific to each growth pattern) on the dependent variable (economic growth). While these four countries differ, as do the domestic and international circumstances under 
which they experienced a particular stage of development, this does not necessarily invalidate the assumption of constant effect.

The choice of countries to compare China to is a subjective choice, motivated only by the desire to make comparisons across a relatively homogeneous group of countries. China may share some economic growth patterns with Japan, Korea, and Taiwan due to cultural similarities, geographic location, similar economic development strategies, or, in the case of Japan, relatively large size of the domestic economy. Limiting the analysis to Japan, Korea, and Taiwan allows the careful compilation of the necessary data from each individual country's statistical office, with a very few missing data points obtained from the World Bank Development Indicators database, the International Financial Statistics (IFS), and the PWT. ${ }^{14}$ The individual data sources, with explanations, are documented in an appendix. ${ }^{15}$ An attempt was made to cover the years 1950 through 2005 but data are often available only since the 1960s or 1970s. The earlier in the development process of Japan, Korea, and Taiwan, the closer to the case of China the initial conditions might have been. Data on China are for the years of the reform period (the years since 1978).

Throughout, the variable to be explained is real GDP growth per laborer, because GDP is produced only by the active working population, namely laborers (one PWT figure, Figure 6, by necessity uses per capita figures). ${ }^{16}$

\section{a. Structural change}

As labor shifts from low-productivity agriculture to higher-productivity industry and services, economy-wide real GDP per laborer, i.e., (partial) labor productivity, increases, if only because those laborers who have shifted sectors now produce a multiple of their former output value. Figure 1 shows just how big, and increasing, the labor productivity differences are between the three economic sectors in China. One would expect to see relatively high aggregate (economy-wide) labor productivity growth in those years when a relatively large number of laborers shifts out of agriculture.

Figure 2 confirms the expectations. Each data point reflects a particular country in a particular year. In years with a high absolute reduction in the share of laborers in agriculture, 
the growth rate of (real, likewise below) labor productivity is high. This pattern holds equally for all four countries. Among Japan, Korea, and Taiwan, the shift out of agriculture was, on average, fastest in Korea, followed by Taiwan and then Japan (Figure 3); this matches the initial shares of laborers in agriculture, with the highest one in Korea and the lowest one in Japan. One would consequently expect China, with an extremely high share of laborers in agriculture in 1978, to exhibit rapid reductions in this share, comparable perhaps to Korea, but the decline is more gradual. ${ }^{17}$

At China's 1978-2005 rate of decline in the share of laborers in agriculture from just above $70 \%$ to $45 \%$, with an annual reduction in the share of laborers in agriculture by, on average, an absolute value of 0.01 every year (thus, for example, from 0.7 to 0.69 in one year), China has another 35 years to go before its agricultural labor share reaches the $10 \%$ level at which the agricultural labor share of Japan, Korea, and Taiwan stabilize. But this implies that China faces another 35 years of structural change as a source of economic growth. Furthermore, in China, a given shift out of agriculture comes with higher labor productivity growth than in any of the other three countries. In Figure 2, the observations for China tend to lie above those of the other three countries. ${ }^{18}$

\section{b. Catching up}

Catching up means that production techniques and technologies that have already been invented and implemented can be copied rather than need to be re-invented; technology transfer can also happen through the import of foreign equipment, possibly as part of foreign direct investment. Taking the U.S. as the leader in research and development, and proxying the level of technological development by labor productivity, the distance between a particular country's labor productivity (in USD) and U.S. labor productivity serves as a measure of the potential scope for catching up. One would expect to see relatively high real GDP growth per laborer in those cases where the distance to the leading country (the U.S.) is relatively high, i.e., where the potential for catching up is large. ${ }^{19}$

Figure 4 confirms the hypothesis for Japan. ${ }^{20}$ Japan experienced its highest growth rates when its labor productivity was ten to fifty percent of U.S. labor productivity. As the gap 
closed, growth rates in Japan fell. (The trend curve shows a slight upswing at the highest labor productivity levels as an artifact of the imposed second-degree polynomial.) Korea and Taiwan exhibit constantly high growth rates of labor productivity at an average $4 \%$ to $5 \%$ throughout all years (Figure 4). These two countries' level of economic development has so far remained in the range of $5 \%$ to $50 \%$ of the U.S. level, a range in which Japan also exhibited high and constant labor productivity growth rates. Korea and Taiwan may yet have to experience the slow-down that comes when the potential gains from catching up are exhausted. China has remained within such a narrow range of (low) development that it is not possible yet to discern a meaningful pattern. Figure 5 shows that China's labor productivity between 1978 and 2005 was only 1.2 to $3.4 \%$ of that of the U.S. (using the official exchange rate to translate Chinese yuan RMB values into USD values). At China's highest level of catching up so far, the growth rate of labor productivity was at a relatively high $9 \%$.

Figure 6 replicates Figure 4 using PWT data. PWT data adjust for differing price levels across countries and may also, as in the case of China, undertake further adjustments to official data. ${ }^{21}$ The PWT data are per capita (rather than per laborer); the observations for China are as always limited to the years since 1978. The pattern now is one of first rising labor productivity at low development levels before gradually falling off. This might reflect initial opening up effects as barriers to foreign direct investment and imports are removed and access to foreign knowledge increases. The Chinese observations are again concentrated in a very narrow band.

Independent of the choice of data, China is at a very low development level compared to the U.S. It appears to be at a stage of economic development (labor productivity) where other Asian countries started out more than 30 years ago. ${ }^{22}$

\section{c. Factor price equalization}

The factor price equalization theorem (or Heckscher-Ohlin-Samuelson theorem) states that factor prices, such as skill-specific wages, should equalize between two countries as long as a range of assumptions are met. I.e., the skill-specific wage rate of one country divided by that of the other country should equal unity. ${ }^{23}$ The slightly less restrictive, relative version of 
the factor price equalization theorem focuses on the relative prices of factors of production. Thus, for example, a country with labor that is cheap relative to capital should see demand for its labor rise. As underemployed laborers become fully employed (or labor shifts out of lowproductivity agriculture), labor productivity rises. ${ }^{24}$ In the absence of reliable prices of capital, the price of capital is approximated here by the price of investment goods. The price of investment goods of any particular country relative to the U.S. is available in the PWT.

Figure 7 reveals a clear downward slope for Japan. Relative factor price equalization, at $10-40 \%$ of the U.S. level, appears to have little effect on Korea and Taiwan, which experience continuously stable labor productivity growth, with perhaps a slight decline in the most recent years (when approaching 50\% of the U.S. level). The observations for China, also reproduced at a larger scale in Figure 8, are within such a narrow range, at only $2-7 \%$ of the corresponding U.S. ratio, that a clear pattern does not yet emerge. China's level of relative factor price equalization is well below the early levels of the other three Asian countries. If China were just at the beginning of a long-run trajectory, then the patterns of the other three Asian countries suggests that China's potential for economic growth from relatively low labor costs will continue to exist for another thirty years. ${ }^{25}$

This section focused on three explanations of economic growth from development economics and trade theory, and applied them to the case of China. China's past economic growth matches these standard development patterns, as does economic growth in Japan, Korea, and Taiwan. In as far as China is located at the early stages of each pattern, in comparison to Japan, Korea, and Taiwan, there remains much scope for future gains in labor productivity and therefore growth.

\section{Growth Accounting}

Growth accounting decomposes GDP growth into growth of variables other than GDP. I.e., growth of GDP is "explained" by the weighted growth rates of other variables. One need not view these other variables as constituting a satisfactory final explanation of GDP growth; for the purpose of forecasting future economic growth, regularity in the relationship with output suffices. ${ }^{26}$ If GDP growth and the growth of the variables into which it is decomposed 
exhibited a stable relationship in the past, and if this stable relationship is likely to continue into the future, then information about the future values of the variables into which GDP has been decomposed allows derivation of future GDP growth.

One growth decomposition uses the production function framework. Estimation of an economy-wide time series production function (in various forms) for China in 1978-2002 yields largely insignificant coefficients. I.e., in the typical Cobb-Douglas production function, the output elasticities are not constant over time. Perhaps for good reasons, authors from Wang Yan and Yao Yudong (2003) to Alwyn Young (2003) did not estimate a production function, but simply assumed weights with which to combine labor and capital growth (plus a residual) into GDP growth. ${ }^{27}$ The weights are assumed constant over time, and set approximately equal to the factor shares; underlying this procedure are the assumptions of constant output elasticities (despite the evidence to the contrary) and perfect competition (unlikely to be met, at least not in the pre-reform planned economy). ${ }^{28}$

A different growth decomposition that is free of assumptions and works with identities follows the income approach to the calculation of GDP. In the income approach to the calculation of GDP, GDP is defined as

GDP $\equiv$ labor remuneration + depreciation + net taxes on production + operating surplus. These data are available for China, for all years of the reform period, at the provincial but not the national level. Summing across provinces, and applying the sum provincial shares of the different income components to national GDP yields an approximation of national income components. $^{29}$

Net taxes on production reflect taxes on production, such as the value-added tax, less production subsidies, such as subsidies for policy losses, price subsidies for the grain system, and tax refunds for exporting enterprises. The largest part of this income component is likely to depend on value-added. Net taxes on production are in the following taken to be a function of GDP.

Depreciation depends on the value of not yet fully depreciated fixed assets. It is in the following taken to be a function of capital. 
The operating surplus is a residual. It approximately reflects economy-wide business profit. ${ }^{30}$ Operating surplus is the return to the owners of the capital involved in a productive activity, and thus constitutes the economy-wide return on equity. Consolidating balance sheets across the economy and eliminating the financial sector so that household savings at banks combined with bank loans to enterprises translate into household claims on enterprises, operating surplus constitutes the return on fixed assets, intangible assets, and inventories. Since inventories are not productive, operating surplus is largely a function of fixed and intangible assets. With data on land values not available (and presumably even today much smaller than the value of fixed assets), only fixed assets remain as feasible argument.

The national income equation can then be rewritten as

(1) $P_{t} Y_{t} \equiv w_{t} L_{t}+\delta_{t} K_{t}+\tau_{t} P_{t} Y_{t}+s_{t} K_{t}$, or

$$
Y_{t}^{\tau} \equiv Y_{t}\left(1-\tau_{t}\right) \equiv \frac{w_{t}}{P_{t}} L_{t}+\left(\delta_{t}+s_{t}\right) \frac{K_{t}}{P_{t}}
$$

where $\mathrm{P}$ denotes the price level, Y real GDP, w the wage rate, $\mathrm{L}$ the quantity of labor, $\mathrm{K}$ the nominal capital stock, and $\delta_{\mathrm{t}}, \tau_{\mathrm{t}}$, and $\mathrm{s}_{\mathrm{t}}$ are the depreciation rate, the net tax rate on production, and the surplus rate. Taking derivatives with respect to time and dividing by GDP less net taxes on production, while expanding right-hand side terms, yields

$$
\begin{aligned}
\frac{\frac{d Y_{t}^{\tau}}{d t}}{Y_{t}^{\tau}} \equiv \frac{\frac{d Y_{t}}{d t}\left(1-\tau_{t}\right)}{Y_{t}\left(1-\tau_{t}\right)}-\frac{Y_{t} \frac{d \tau_{t}}{d t}}{Y_{t}\left(1-\tau_{t}\right)} \\
\\
\equiv \frac{d \frac{w_{t}}{P_{t}}}{\frac{d t}{P_{t}}} L_{t} \frac{w_{t}}{P_{t}}+\frac{w_{t}}{Y_{t}} \frac{L_{t}}{Y_{t}^{\tau}} \frac{\frac{d L_{t}}{d t}}{L_{t}}+\frac{d \delta_{t}}{d t} \frac{K_{t}}{\delta_{t}} \frac{\delta_{t}}{Y_{t}^{\tau}}+\frac{\frac{d s_{t}}{d t}}{s_{t}} \frac{K_{t}}{P_{t}} \frac{s_{t}}{Y_{t}^{\tau}}+\left(\delta_{t}+s_{t}\right) \frac{\frac{K_{t}}{P_{t}}}{\frac{d t}{K_{t}}} \frac{K_{t}}{P_{t}} \\
Y_{t}^{\tau}
\end{aligned}
$$

Using hats to denote growth rates and abbreviating the shares of labor, depreciation, and operating surplus in 'GDP less net taxes on production' by $a_{t}{ }^{\tau}, d_{t}{ }^{\tau}$, and $e_{t}{ }^{\tau}$ leads to the income growth accounting equation 
(2) $\hat{Y}_{t}^{\tau} \equiv \hat{Y}_{t}-\frac{\frac{d \tau_{t}}{d t}}{\left(1-\tau_{t}\right)} \equiv a_{t}^{\tau}\left(\frac{\hat{w}_{t}}{P_{t}}\right)+a_{t}^{\tau} \hat{L}_{t}+d_{t}^{\tau} \hat{\delta}_{t}+e_{t}^{\tau} \hat{s}_{t}+\left(d_{t}^{\tau}+e_{t}^{\tau}\right)\left(\frac{\hat{K}_{t}}{P_{t}}\right)$.

Like the traditional growth accounting equation, the income version represents one form of GDP decomposition. Compared to the traditional growth accounting equation, the income version newly introduces the growth rates of the real wage rate, the depreciation rate, the surplus rate (or "rental rate of capital"), and the net tax rate on production; in exchange, there is no room for a residual. There is also no need for assumptions since it is a definitional identity. What is called "technological progress" (the residual) in the traditional growth accounting equation, is now measured as (and is identical to the) weighted rate of change in real wages, the depreciation rate, the surplus rate, and a particular form of change in the net tax rate on production. ${ }^{31}$

In the period 1978-2002, nominal GDP deflated by the implicit deflator as first published grew by $827 \%$, and nominal GDP less net taxes on production, deflated by the implicit deflator as first published, grew by $814 \%{ }^{32}$ The difference of only thirteen percentage points implies that the changes in the net rate of taxes on production are negligibly small. The income decomposition, using the average income shares of 1978-2002-following the standard Tornqvist method of weighting factor growth with the mean of the previous and current period's weights - is as follows:

$$
\begin{aligned}
& \hat{Y}_{t}^{\tau} \equiv a_{t}^{\tau}\left(\frac{\hat{w}_{t}}{P_{t}}\right)+a_{t}^{\tau} \hat{L}_{t}+d_{t}^{\tau} \hat{\delta}_{t}+e_{t}^{\tau} \hat{s}_{t}+\left(d_{t}^{\tau}+e_{t}^{\tau}\right)\left(\frac{\hat{K}_{t}}{P_{t}}\right) \\
& 814 \% \cong 0.5981 * 495 \%+0.5981 * 60 \%+0.1370 * 16 \%+0.2649 *(-50 \%)+0.4019 * 1185 \% \\
& =296 \%+36 \%+2 \% \quad-13 \% \quad+476 \%=797 \%
\end{aligned}
$$

In the period 1978-2002, growth in constant-price capital accounted for approximately $60 \%$ of real GDP growth (476/797) and growth in real wages for 37\%; growth in the quantity of labor contributed just below 5\%, with the remainder due to very small positive and negative contributions of changes in the depreciation rate and in the surplus rate. (For the individual data, see Table 2.) 
The income growth accounting version only holds with perfect accuracy in the instantaneous case when growth rates are infinitesimally small and the factor shares at a given point of time therefore are exactly applicable. Measuring growth rates over 24 years introduces a discrepancy of $814 \%$ vs. $797 \%$ due to the need to apply average factor shares. The discrepancy is small, i.e., using mid-period weights has little impact on the outcome. The share of labor remuneration was rather constant in the period 1978-2002, with a mean of 0.5981 and a standard deviation of 0.0110 (Figure 9). The share of depreciation rose from 0.1113 in 1978 to 0.1823 in 2002 (with a mean value of 0.1370 and a standard deviation of 0.0241 ), and the share of the operating surplus fell from 0.3191 to 0.2253 in the same period (with a mean value of 0.2649 and a standard deviation of 0.0286 ). However, the two shares appear individually only in the products with the growth rate of the depreciation rate and of the surplus rate, and these products are relatively small. The weight of real capital is again constant (as the sum of the depreciation and surplus shares, or unity less the labor share).

Since the product of the depreciation share and depreciation rate growth in the income decomposition of GDP contributed only $0.25 \%$ of total growth in 1978-2002, and the product of surplus share and surplus growth only (negative) $1.63 \%$, these two terms are in the following forecasts ignored. This implies that what is needed to re-compose future GDP growth via the income growth accounting equation are only the growth rates of real wages, labor, and real capital.

The future growth rates of the quantity of labor is readily available if one is willing to make a few, plausible assumptions. Those age 15 in 2015 (the minimum working age) were already born at the time of the year 2000 population census, i.e., forecasts through 2015 are highly reliable, and in as far as trends in reproduction rates have been stable in recent years, forecasts through later years are likely to only gradually lose reliability. ${ }^{33}$

What remains is to calculate future growth rates of real wages and of real capital. Ideally, these growth rates are related as much as possible to variables whose future values are already known today, namely the quantity of labor, the quality of labor, and age measures. These are natural explanatory variables for real wages when the unit of analysis is the individual. ${ }^{34}$ Since they are the only hard facts we have about the future, they are also used to 
explain real capital. This is plausible at least for the quality of capital, because more sophisticated capital is likely to require a higher level of labor quality. To some extent it may even be plausible for the quantity of capital, if agriculture requires little education and little capital, and those who move into other sectors with a higher capital-output ratio are the most educated.

Examining three dozen potentially wage-related variables in the period 1978-2002, from average years of schooling and share of laborers with a particular level of schooling (primary, lower middle, upper middle, college, university, post-graduate) to age characteristics and potentially relevant non-labor variables, such as the share of foreign direct investment in total domestic investment, most of these series are unit root processes.

The solution then is to find a long-run relationship using the data of the period 1978-2002. First, for real wages, the potentially relevant variables were inspected visually for trends, then subjected to the appropriate augmented Dickey-Fuller unit root and Phillips-Perron tests for unit roots in levels, and in first and second differences. The real wage rate, as many other variables, is an I(1) process. All tests were conducted for variables in levels as well as in natural logarithms. Second, in order to determine the lag length for cointegration testing, unrestricted VARs were estimated using the real wage rate and one to three other variables (in approximately three dozen different combinations), starting with four lags and reducing the lags one at a time. ${ }^{35}$ Third, the different combinations of the real wage rate with other variables were tested for cointegration at the lag lengths previously determined; since in all cases at least one series exhibited a clear trend, cointegration testing was conducted with a constant in the cointegating equation as well as in the VAR, and, alternatively with, in addition, a trend in the cointegrating equation. If a significant eigenvector (relying on both the trace test and the maximum eigenvalue test) was found, a vector error correction (VEC) model was estimated. Models with one or more insignificant coefficient in the cointegrating equation were dropped. Table 4 reports two long-run relationships embedded in the vector error correction models, one with variables in levels, the other with variables in logarithms. The same procedure was used for real capital and those results are also reported in Table $4 .{ }^{36}$ (For the labor data of the future, see Table 3.) 
The first long-run relationship (cointegrating equation) reported in the table is between the wage per laborer, the share of laborers with upper middle school education, and the share of laborers with college level education or above. For simplicity of exposition, the relationship is expressed with the wage per laborer as left-hand side variable. The larger the share of laborers with upper middle school education, the lower the wage; the larger the share of laborers with college level education or above, the higher the wage. Moving further down the first column, none of the variables Granger-causes one of the others. ${ }^{37}$ Forecast error variance decomposition shows that much of the movement in the wage series is due to its own shocks, but over a ten-year forecast horizon, $22 \%$ of the forecast error variance of the wage series is due to shocks to the share of laborers with college level education or above. ${ }^{38}$

The other three cointegration equations reported in the table all have plausible (and significant) coefficient signs; the two cases where variables are in natural logarithms reveal strong Granger causality from the education variables to the wage and capital series; over a 10 -year forecast horizon the forecast error variance of capital is mostly accounted for by shocks to one of the education variables. The logic behind the use of the variable "average years of schooling minus five" in three cointegration equations (squared in one case) is that a primary school education is standard, and wage differentiation then depends only on the number of years of schooling in excess of primary school education. While primary school lasts for 6 years, the 1978 average years of schooling is just below 6 years; in order to have a positive variable throughout (necessary to take logarithms), 5 years is used as a benchmark. ${ }^{39}$

Table 5 reports the average annual growth rates of the three variables wages, capital, and labor, and then the resulting GDP growth rates, all in 5-year periods as well as over the total period 2000-2025. The first four data columns report the growth rates obtained by fitting the four cointegration equations of the previous table to the forecast education and labor data through 2025. When the cointegration equations are estimated in logarithms, the resulting growth rates tend to be higher, especially far into the future. The forecast quantity of labor series (fifth data column) has a falling positive growth rate that eventually (by 2014) turns negative. 
Assuming a constant depreciation rate, surplus rate, and net tax rate on production (as the decomposition for the period 1978-2002 suggests is permissible), future GDP growth can be obtained by summing the growth rates of wages, capital, and labor; in each year, the weights, in form of the tax-adjusted labor share and one minus this share, are the previous-year values (for details see notes to the table). Depending on if the cointegration equation using variables in levels or in logarithms is used, the resulting average annual GDP growth rate of the period 2000-05 is 5.80 or $8.09 \%$ (sixth and seventh data columns in the table). With actual real growth in this period likely to be between 8 and $9 \%$, the second series, with the cointegration based on variables in logarithms, seems to be more accurate. In the periods 2005-10 and $2010-25$, the two series yield rather similar estimates, in the range of $7.05-9.42 \%$. At this level of economic growth, the extrapolations of Table 1 suggest that China will surpass the U.S. economy in size, using the purchasing power concept, around the middle of the next decade.

Further into the future, the predictions diverge significantly, with one GDP growth series falling off, and the other rising. Due to the recent explosion in education, the out-of-sample forecasts use education values that are far from sample average values. As the educational level of laborers increases, the marginal product of education could fall, and the predicted wage values then constitute an overestimate; on the other hand, if labor is increasingly paid its marginal product value rather than state-ordained wages, the predicted wage values are likely to constitute an underestimate. The comparison of the two GDP growth series shows well the degree of uncertainty involved in predicting further into the future than 2015 . The two series reflect extreme scenarios. A different combination of wage and capital series yields intermediate growth values.

An alternative approach to predicting GDP growth is to assume a constant labor share. This is plausible given worldwide experiences. Figure 10 shows that it is also plausible given past labor share values in China (now labor share in GDP, not in GDP less net taxes on production). ${ }^{40}$ Given the definition of the labor share as labor remuneration divided by GDP, and, if dividing numerator and denominator by the price level, as 


$$
a_{t} \equiv \frac{\frac{w_{t}}{P_{t}} L_{t}}{Y_{t}},
$$

and assuming the labor share $\mathrm{a}_{\mathrm{t}}$ to be constant, yields the growth rate of real GDP as

$$
\hat{Y}_{t} \equiv \frac{\hat{w}_{t}}{P_{t}}+\hat{L}_{t}
$$

I.e., real GDP growth is simply the sum of real wage growth and labor growth. Data on future labor growth through approximately 2025 are available. Real wage growth is plausibly explained by the quantity and quality of labor. The relationship for the period 1978-2002 was identified above and can be applied to the reliable data on the future quantity and quality of labor available through approximately 2025. This procedure by-passes the need for a capital series. Table 5 in the last two columns reports the results. They carry no new or different insights but confirm the findings following the more elaborate decomposition of GDP growth by income categories.

The above growth forecasts rely solely on facts about the future quantity and quality of laborers in China, facts that are near-certain today, and the assumption that the past relationship between wages and labor variables (and, in one scenario, also between capital and labor variables) continues to hold in the future. With little change in China's labor force over the next twenty years, economic growth depends on growth in the wage rate and, in the decomposition of GDP growth by income categories, also on the accumulation of physical capital, variables that are in the estimations driven by labor quality. The next section explores in more detail the most recent developments in human capital formation in China.

\section{Human Capital}

Growth in human capital in reform period China has been rapid. A comparison with the U.S. puts China's human capital measures into perspective, while the development of education in China over time reveals the scale of changes underway.

Table 6 compares the educational level of the Chinese vs. U.S. population as reported in the population censuses of 1990 and 2000 in both countries. ${ }^{41}$ As a percentage of the total population, a far higher proportion of the U.S. population has achieved a secondary or tertiary 
level of education. For example, in 1990, 75.2\% of the U.S. population had completed high school (or above), but only $9.52 \%$ of the Chinese population had; $20.3 \%$ of the U.S. population had completed a bachelor's degree (or above), but only $0.56 \%$ of the Chinese population had. But because the U.S. population in 1990 was only $28 \%$ of the size of the Chinese population (in 2000, 24\%), the difference shrinks by a factor of approximately four once total population numbers are considered.

Between 1990 and 2000, China narrowed the relative gap. While in 1990 the number of U.S. citizens with high school education was 1.65 times the number in China, by 2000 this ratio had fallen to 1.17 (last column in Table 6). For the BA degree, the ratio fell from 7.59 to 4.33. At the level above the bachelor's degree the ratio in 2000 was still 21.42 in favor of the U.S. (with no such figure available for 1990).

These data cover the population in total. But the educational level of different age cohorts in China is changing rapidly over time. Figure 11 shows that in 2000 more than half the population age 65 or above had a level of education below primary school; only $10.55 \%$ had some form of secondary education (lower or upper middle-school), and 1.50\% had a tertiary level education. In contrast, in the age cohort 20-29 years, only $2.06 \%$ had a level of education below primary school, $20.98 \%$ completed only primary school, $69.44 \%$ achieved some form of secondary education, and $7.53 \%$ obtained a tertiary level education. The age cohorts in between reveal a smooth transition from the less educated older generation to the ever better educated younger age cohorts. ${ }^{42}$ The Chinese age cohort of 20-29 years in 2000, at the primary and secondary school level, comes close to the U.S. population average, but in tertiary education still falls far short.

Current-year new enrollment data at the tertiary level reveal that at the BA level (including college-level associate degrees) China has caught up with the U.S. Figure 12 shows the number of newly enrolled students in Chinese BA programs, in contrast to the U.S. In the reform period, new enrollment in China first languished, but began to expand gradually in the early 1980s and then rapidly after 1998. In 1998, new enrollment was at approximately twice its 1978 level. In the course of the following 7 years, between 1998 and 2005, new enrollment quintupled. Since 2001, the absolute new enrollment number in Chinese BA 
programs at (only) regular institutions of higher education exceeds the number of freshmen in the U.S. In 2005, China's new enrollment figure was twice that of the U.S., and in 2006 it was scheduled to rise by another $5 \%{ }^{43}$

Data on the joint category of MA and PhD new enrollment in China (also Figure 12) follow the same trend as new enrollment for the BA/ college-level associate degree. Lacking data on new enrollment at the graduate level in the U.S., and therefore assuming that the 1998 (and projected 2005) graduation number of 476,174 $(609,200) \mathrm{MA}$ and $\mathrm{PhD}$ degree holders is an accurate indicator of current new enrollment, U.S. enrollment numbers at the graduate level were seven times the Chinese figure of 72,508 in 1999 , but only one-third above the Chinese figure of 364,831 in 2005.

With new enrollment at the tertiary level in China rising drastically in recent years, so does the number of graduates (Figure 13). The absolute number of undergraduate level graduates in China began to exceed that in the U.S. in 2004, and in 2005 was 50\% higher. ${ }^{44}$ Based on the enrollment numbers of 2005 (and the significant drop-out rates in the U.S.), by 2008/09 the number of undergraduate level graduates in China should be 2.5 times the U.S. number.

At the MA and PhD level (with only joint data available for China), the U.S. in 1998 had had a 10-fold lead in absolute graduation numbers (Figure 13). ${ }^{45}$ But by 2005 the gap narrowed to a 3-fold lead, while the 2005 enrollment numbers suggest the gap to narrow to perhaps $70 \%$ of the Chinese number of graduates in $2008 .{ }^{46}$

At the high school level, the number of Chinese graduates has well exceeded their U.S. counterpart in absolute numbers throughout the reform period. In 2005, China had 2.69 times more high school graduates than the U.S. ${ }^{47}$

Head count data do not necessarily translate into comparable accumulation of human capital since they reveal nothing about the quality of education. ${ }^{48}$ But it is not at all certain that education in China through the secondary school level is necessarily inferior to that in the U.S. Even at the tertiary level, a provincial railway ministry college in China need not be inferior to a U.S. community college. At the top range of tertiary education, the conclusion is 
likely to be far less ambiguous; but at that level, Chinese students seem to make good use of U.S. institutions.

The explosion in education is only happening since the late 1990s. Much of the upgrading in the education level of Chinese laborers will not be felt until some years later. This again implies a fair amount of uncertainty about where exactly China's economy will be by 2025 . Not all the additional graduates are likely to be as qualified as the average graduate of earlier generations. On the other hand, with current private returns to education possibly far below the marginal product value, further reforms could mean a more important role for education in economic growth in the future.

\section{Conclusions and Implications}

Extrapolation of China's reform period economic growth into the future suggests that the size of China's economy will exceed that of the U.S., in purchasing power parity terms, in about five years. Per capita, the point of time when China catches up with the U.S. is much further into the future, twenty to fifty years from now, although the coastal areas, especially the in the past fastest growing five provinces, with a population exceeding that of the U.S., may catch up in as little as one to two decades.

China's economic development in the reform period fits well with the broad development patterns of structural change, catching up, and factor price equalization, not least in comparison with other Asian countries earlier in their economic development. On all accounts, China has twenty to forty more years of gains in economic growth to reap. Recomposing China's economic growth from growth in income components suggests that China's continued growth is inevitable. Based on the year 2000 population census combined with past and current trends in education, the quantity and quality of China's laborers can be predicted with near-certainty through 2015 , and with high reliability for the years after. Translating these reliable labor forecasts into GDP growth under the assumption that the past relationship between wages (and, in one instance, capital) and labor variables continues to hold, suggests economic growth between 2005 and 2015 in the range of 7-9\%, high enough for China to catch up with the U.S., in purchasing power terms, within about five years. 
Growth accounting illustrates the correlation between changes in the educational structure of China's population and economic growth. China's population is four times the size of the U.S. population. If talent is randomly distributed among the world population and if China's education system is able to identify the brightest students, then China has a larger pool of talent to draw from than any other country in the world. ${ }^{49}$ If innovation depends on the agglomeration of talent (geographically, nationally, culturally, or linguistically), then China is in an excellent position to grow and innovate. ${ }^{50}$

China's demographics and economic growth have a number of implications. The sheer size of its future pool of highly educated persons raises questions about the long-run leadership of the West in technological innovation. The explosion in China's education system is happening only now and will take ten to twenty years before it feeds through into a, on average, substantially better educated labor force. It also takes some years for new graduates to gain their first job experience. This suggests that China's challenge to the technological leadership of the West will only happen gradually, as a matter of twenty or more years.

China's recent explorations in space suggest that China's talent may initially be focused on specific industries, in this case due to special support by the state. In general, it is only when profits can no longer be made in a particular sector by using existing technologies or upgrading to known technologies, that pressure for indigenous innovation sets in. Since not all industrial sectors develop at the same pace, China is unlikely to technologically advance on all fronts simultaneously.

Demographics also matters in terms of market size (and $80 \%$ of China's population lives in the densely populated Eastern part of the country). Size of the domestic market should allow unprecedented variety and economies of scale. Economies of scale lead to low cost. A large number of suppliers suggests a high degree of competition and pressure on prices; eventually, decreasing profit margins create incentives to innovate in order to either lower costs further or to be able to offer a more differentiated product with higher profit margins. The price wars that started in the late 1990s are evidence of the degree of price pressures that 
pervade some Chinese industries. ${ }^{51}$ Upgrading to newer technologies and switching to indigenous innovation may happen more rapidly in China than it has elsewhere.

China's ongoing rapid economic growth implies that one-fifth of the world population will continue to experience significant improvements in their living standard. A share of China's population that exceeds the size of the U.S. population will enjoy living standards close to the level of developed countries in the near future. In the Chinese hinterland, the rise out of poverty continues. Consumption waves similar to those that the most developed countries have experienced in the past are unfolding in China, albeit with some variations, such as the early introduction of the cell phone.

In production, the sweatshops of early industrialization are disappearing sooner rather than later. With first labor shortages in Guangdong province in 2005, wages of unskilled labor have begun to rise, and labor standards are increasingly being enforced. From the creation of capital markets to the establishment of a nationwide social security system, what has taken the West centuries, is condensed into decades in China.

China's economic growth has international repercussions. China's trade volume is exceptionally large by international standards. In 2000, China's ratio of 'exports of goods and services' to GDP was $25.90 \%$, compared to $11.17 \%$ for the U.S. ${ }^{52}$ By 2005 , China's ratio of exports of goods and services to GDP at $37.44 \%$ was more than ten percentage points higher (while imports stood at $31.86 \%$ ), compared to a rather constant $10.42 \%$ in the case of the U.S. ${ }^{53}$ Even if this export share of China only stays constant in the future rather than rises further, China's economic growth means that China will soon be the world's largest exporter and importer.

Two-thirds of China's imports originate in Asia (where it sends half of its exports). China's economic growth, therefore, induces economic growth in particular in other Asian countries. Beyond trade, India may be tempted by China's example into sustained, growthpromoting economic reforms.

China's economic growth affects relative prices around the world, thereby promoting an increasing division of labor and specialization worldwide. This implies structural changes within countries; some industries in each economy benefit from China's economic growth, 
while others lose out. The restructuring extends beyond the traditional realms of manufacturing, to services. For example, the newly rich in China's coastal provinces are likely to become the next wave of tourists to the West, while other services, such as backroom banking services, might gradually shift from the West to China.

With China's labor costs on the rise and the RMB appreciating, the "China price" is unlikely to further affect international markets in which Chinese suppliers are currently already present. The "China price," however, remains relevant for markets that Chinese suppliers have not yet entered. As Chinese producers move up the product ladder, previously sheltered Western markets will newly experience downward price pressures (due to the entry of Chinese firms, or to the shift of production by Western firms from the West to China). Given the size of the population of China — and eventually that of India — previous niche markets in the West may increasingly turn into international mass markets.

China's current strength in unskilled labor and mass production implies a wage constraint for unskilled laborers employed in Western industries producing tradables. The possibility of a permanent loss in-average - per capita real income in the U.S., suggested by Paul Samuelson based on a simplified trade model (see the introduction above), is not implausible. In Europe, where labor appears particularly slow to adjust to sectoral shocks, downward wage pressure could well translate further into increasing rates of unemployment.

China is a relatively resource-scarce country, and its economic growth has supposedly already affected the world market price of natural resources. But as long as these natural resources exist, China's impact on long-run world market prices is minor. As soon as the supply of these natural resources has increased, short-term price increases will be reversed. In the long run, the prices of natural resources increase only if the marginal cost of extraction increases (or cartels manage to fix prices / constrain production).

In the case of energy resources, this implies that world oil prices are likely to return to the marginal cost of extraction (plus normal profits). China's economic growth may bring into play three additional, energy-related factors. First, China relies primarily on coal for energy production; throughout the reform period, coal provided $75 \%$ of China's energy. ${ }^{54}$ Presumably there is much scope for innovation to improve the energy efficiency of coal use 
in China. Second, the relative costs of energy production in China differ from those of the world. Given China's relatively low labor cost, labor-intensive energy sources enjoy a comparative advantage in China. Thus, with coal extraction likely to be more labor-intensive than petroleum extraction, coal enjoys a relative edge in China. Similarly, the production of solar panels, wind turbines, and small-scale hydropower stations all may enjoy a relative price advantage in China. To the extent that these energy sources can be exported, the cost of their production in China may provide another (new) anchor for energy prices worldwide (besides marginal costs of extraction of petroleum). Third, any pressure that China exerts on world energy resources implies incentives to explore new energy resources. China's economic growth, thus, is likely to accelerate research into new sources of energy and into the more efficient use of current sources of energy. ${ }^{55}$

Finally, given China's economic growth and the size of its trade volume, once China liberalizes its capital account the RMB is likely to play an increasingly important role as a world currency, either on its own, or eventually as part of an Asian currency. This has implications for the use of the USD and the Euro as standard currencies in international trade, and ultimately on the volume of seignorage that the U.S. and Europe can enjoy.

Within the next five to ten years, the growth of China—-followed by the growth of India and of South East Asia and combined with the economic size of Japan and Korea-implies that the center of world economic activity will increasingly shift to Asia. Shocks to the U.S. and European economies, or stagnation of these economies, will have less and less impact on Asia. In 2005, 21.38\% of China's exports of goods went to the U.S., and 21.74\% to Europe; even if the U.S. and Europe were to gradually increase protectionist measures, the impact on China would be minor. ${ }^{56}$

But the West also plays an important role in China. In 2004, the most recent year for which the data are available, $19.23 \%$ of gross output value of industrial enterprises with annual sales revenue in excess of 5m yuan RMB (USD 0.6m) within China was produced by foreign-funded enterprises, a figure which excludes an additional 10.97\% in enterprises funded by Hong Kong, Macao, and Taiwanese entrepreneurs. ${ }^{57}$ I.e., non-domestic enterprises account for approximately one-third of Chinese industrial output, or, in other words, non- 
domestic entities control one-third of Chinese industry. To the extent that Western pension funds invest in these non-domestic firms, often multinational corporations, Western citizens directly benefit from (and depend on) China's continued economic growth.

The foreign-funded industrial enterprises alone, with their approximately one-fifth share of industrial output in China, accounted for 58.30\% of China's exports in 2005 (and 58.71\% of China's imports). ${ }^{58}$ This suggests that China's exports to the West largely reflect the West "importing" from "itself," where the West's nationals, or firms incorporated in the West, simply use Chinese labor in their production processes.

On many measures, China is an extremely open economy. China is adopting international standards and practices on a scale and at a speed as perhaps no other county in the world ever has. China, always with some local adjustments, copies the Company Law and stock market regulations from the U.S., models its patent office along the lines of the German patent office, adopts international accounting standards, and as early as 1994 asked its bank to adopt the Bank for International Settlements' capital adequacy ratios (with temporary opt-outs for the state-owned commercial banks).

With China always dependent on other countries for the supply of a wide array of natural resources, a fair share of China's industry being run by foreign firms, and Chinese standards and practices oriented towards international standards and practices, China is very much integrated into the world economy. Thus, China's economic growth is not simply a rerun of the industrial revolution in the UK two hundred years earlier, at a much swifter pace, but is accompanied by simultaneous changes in the patterns of production, ownership, and sources of income in economies around the world. The concept of a national economy, and following from that of a new "superpower," appears inapplicable. China is integrated into the world economy to an extent that is similar to that of a European country within Europe. Concepts of "nation" and "citizenship" appear increasingly beside the point. Such political constructs seem to lag behind the emergence of one world economy organized along dimensions of comparative advantage, where the construct of a "nation," in the economic realm, is reduced to issues of enterprise registration, regulation, and taxation. 
Beyond the pure economics, people with "Western" values may feel discomfort at the fact that China is, following its Constitution, a "people's democratic dictatorship ... under the leadership of the Communist Party of China." As China's FDI abroad grows, political questions may become more pressing, such as to what extent Chinese investors abroad are simply extensions of the Politburo (which appoints the managers of 53 of the largest stateowned enterprises), or to what extent the world will increasingly play by the rules of China's $\operatorname{dictator}(\mathrm{s}) ?^{59}$

China's rapid economic rise is not guaranteed. Economic problems range from bad loans in the banking system to an under-funded pension insurance scheme, the lack of a rural health care system, bankrupt local governments, and environmental pollution. Yet China's leadership has a track record spanning more than two decades of rising to economic challenges and addressing problems as they become urgent. ${ }^{60}$ At a $9.6 \%$ average annual real growth rate, furthermore, GDP doubles every eight years. In terms of financial deficits, if the absolute size of a financial problem (or shortage) stays constant during this period, its significance, as a share of GDP, is halved. This provides all the more reason for China's leadership to stay focused on economic growth.

Economic growth also does not necessarily come with the connotation "good." Much of GDP growth could be accompanied by significant environmental degradation and resource exhaustion. A "green GDP" growth rate could be several percentage points lower. ${ }^{61}$ At some point, China's leadership may no longer wish to trade off China's environment and resources for GDP growth. But even once that happens, it is likely to be a gradual process. 


\section{References}

Chinese names in pinyin form are given last name first, followed by first name, without comma in between.

Abramovitz, Moses. "Catching Up, Forging Ahead, and Falling Behind." Journal of Economic History 46, no. 2 (June 1986): 385-406.

Barro, Robert J., and Xavier Sala-i-Martin. Economic Growth. New York: McGraw-Hill, 1995.

Broomfield, Emma V. "Perceptions of Danger: the China Threat Theory." Journal of Contemporary China 12, no. 35 (2003): 265-84.

Brown, Lester Russell. Who Will Feed China? Wake-up Call for a Small Planet. New York : W.W. Norton \& Co., 1995.

Carter, Colin A., and Scott Rozelle. "Will China Become a Major Force in World Food Markets?" Review of Agricultural Economics 23, no. 2 (Fall-Winter 2001): 319-31.

Census 1990. Zhongguo 1990 nian quanguo renkou pucha ziliao (National population census material 1990). Compiled by the State Council population census office and the NBS population division. Beijing: Zhongguo tongji chubanshe, 1993.

Census 2000. Zhongguo 2000 nian quanguo renkou pucha ziliao (National population census material 2000). Compiled by the State Council population census office and the NBS population, society, and science division. Beijing: Zhongguo tongji chubanshe, 2002.

Census 2000 Major Figures. 2000 nian di wu ci quanguo renkou pucha zhuyao shuju (Major figures from the 2000 population census of China). Beijing: Zhongguo tongji chubanshe, 2001.

Census 2000 (nationality). 2000 nian renkou pucha zhongguo minzu renkou ziliao (National population census material 2000 by nationality). Issued by the NBS population, society, and science division. Beijing: Zhongguo tongji chubanshe, 2003.

Chang, Gordon G. The Coming Collapse of China. New York: Random House, 2001.

Chow, Gregory C. China’s Economic Transformation. Malden, MA: Blackwell Publishing, 2002.

Chow, Gregory, and Kui-Wai Li. "China's Economic Growth 1952-2010.” Economic Development and Cultural Change 51, no. 1 (Oct. 2002): 247-56.

Cypher, James M., and James L. Dietz. The Process of Economic Development. London: Routledge, 1997.

Deibert, Ronald. "The Geopolitics of Asian Cyberspace." Far Eastern Economic Review 169, no. 10 (Dec. 2006): 22-5.

Douglas, Allen. "Meet the New China." International Journal of Business 7, no. 3 (2002): 35-49.

Education Yearbook. Zhongguo jiaoyu nianjian (China Education Yearbook). Beijing: Zhongguo jiaoyu chubanshe, annual publication.

Educational Attainment 2000. At http://www.census.gov/prod/2003pubs/c2kbr-24.pdf, accessed on 1 January 2004.

Fifty Years of New China. Xin zhongguo wushi nian tongji ziliao huibian (Compendium of Statistical Materials for the Fifty Years of New China). Beijing: Zhongguo tongji chubanshe, 1999.

Financial Yearbook. Zhongguo jinrong nianjian (China Financial Yearbook). Beijing: Zhongguo jinrong chubanshe, numerous issues. 
GDP 1952-95. Zhongguo guonei shengchan zongzhi hesuan lishi ziliao 1952-1995

(Historical Data on China's Gross Domestic Product 1952-1995). Dalian: Dongbei caijing daxue chubanshe, 1997.

GDP 1996-2002. Zhongguo guonei shengchan zongzhi hesuan lishi ziliao 1996-2002

(Historical Data on China's Gross Domestic Product 1996-2002). Beijing: Zhongguo tongji chubanshe, 2004.

Gertz, Bill. The China Threat: How the People's Republic Targets America." Washington, D.C.: Regnery Publishing, 2000.

Harberger, Arnold C. "A Vision of the Growth Process." American Economic Review 88, no. 1 (March 1998): 1-32.

Heckman, James J. “China's Human Capital Investment.” China Economic Review 16, no. 1 (2005): 50-70.

Henderson, Callum. China on the Brink: The Myths and Realities of the World's Largest Market. New York: McGraw-Hill, 1999.

Heston, Alan. "Treatment of China in PWT 6." Draft, December 2001. At http://pwt.econ.upenn.edu/Documentation/China.PDF, accessed on 16 Dec. 2003.

Heston, Alan, Daniel A. Nuxoll, and Robert Summers. "Comparative Country Performance at Own-Prices or Common International Prices," in M. Dutta (ed.), Economics,

Econometrics and the Link: Essays in Honor of Lawrence R. Klein. Amsterdam: Elsevier, 1995, pp. 345-61.

Holz, Carsten A. China's Industrial State-owned Enterprises: Between Profitability and Bankruptcy. Singapore: World Scientific Publishing Co., 2003. . "The Quantity and Quality of Labor in China 1978-2000-2025." Mimeo, Hong Kong

University of Science \& Technology, May 2005, at http://ihome.ust.hk/ socholz. . "China's Reform Period Economic Growth: How Reliable Are Angus Maddison's Estimates?" Review of Income and Wealth 52, no. 1 (March 2006a): 85-119. . "New Capital Estimates for China." China Economic Review 17, no. 2 (2006b): 142-

85. Data used here are from a previous version (with very small differences in values). . "Why China's Rise Is Sustainable." Far Eastern Economic Review 169, no. 3 (April 2006c): 41-46. . "China's Reform Period Economic Growth: How Reliable Are Angus Maddison's Estimates? Response to Angus Maddison's Reply." Review of Income and Wealth 52, no. 3 (Sept. 2006d): 471-5. . "Measuring Chinese Productivity Growth, 1952-2005." Mimeo, Hong Kong University of Science \& Technology, 22 July 2006(e), at http://ihome.ust.hk/ socholz.

IFS. International Financial Statistics Yearbook. Washington, D.C.: International Monetary Fund, various years.

Klein, Lawrence R., and Suleyman Ozmucur. "The Estimation of China's Economic Growth Rate.” Mimeo, Department of Economics, University of Pennsylvania, 2003.

Lardy, Nicholas R. China's Unfinished Economic Revolution. Washington, D.C.: The Brookings Institution, 1998.

Lin, Justin Yifu, Cai Fang, and Li Zhou. The China Miracle: Development Strategy and Economic Reform. Revised edition. Hong Kong: The Chinese University Press, 2003. Maddison, Angus. "Do Official Statistics Exaggerate China's GDP Growth? A Reply to Carsten Holz." Review of Income and Wealth 52, no. 1 (March 2006): 121-26.

Murray, Geoffrey. China: The Next Superpower. Dilemmas in Change and Continuity. Richmond, Surrey: China Library (Curzon Press), 1998.

Perkins, Dwight H., and Thomas G. Rawski. "Forecasting China's Economic Growth over the Next Two Decades." Draft, 29 June 2006. (Obtained through private correspondence.) 
Price Yearbook. Zhongguo wujia nianjian (China Price Yearbook). Beijing: Zhongguo wujia chubanshe, various years.

PWT6.1. Alan Heston, Robert Summers and Bettina Aten, Penn World Table Version 6.1, Center for International Comparisons at the University of Pennsylvania (CICUP), October 2002. At http://pwt.econ.upenn.edu/.

PWT6.2 Alan Heston, Robert Summers and Bettina Aten, Penn World Table Version 6.2, Center for International Comparisons of Production, Income and Prices at the University of Pennsylvania, September 2006. At http://pwt.econ.upenn.edu/.

Qi Yuanjun. "Guoneiwai luse GDP yanjiu de zongti jinzhan" (Overall progress in research on green GDP in China and abroad). Jingji yanjiu cankao, no. 88/2004: 25-9, 34.

Qian Yingyi. "The Process of China's Market Transition (1978-1998): The Evolutionary, Historical, and Comparative Perspectives." Journal of Institutional and Theoretical Economics 156, no. 1 (March 2000): 151-71.

. "How Reform Worked in China," in Dani Rodrik (ed.), In Search of Prosperity:

Analytic Narratives on Economic Growth. Princeton University Press (2003): 297-333.

Rawski, Thomas G. "Reforming China's Economy: What Have We Learned?" The China Journal, no. 41 (Jan. 1999): pp. 139-156.

Ren Rouen and Chen Kai. "An Expenditure-based Bilateral Comparison of Gross Domestic Product between China and the United States." Review of Income and Wealth 40, no. 4 (Dec. 1994): 377-94.

Samuelson, Paul. "Where Ricardo and Mill Rebut and Confirm Arguments of Mainstream Economists Supporting Globalization." Journal of Economic Perspectives 18, no. 3 (Summer 2004): 135-46.

Statistical Abstract. Zhongguo tongji zhaiyao (China Statistical Abstract). Beijing: Zhongguo tongji chubanshe, various years (annual publication).

Statistical Yearbook. Zhongguo tongji nianjian (Statistical Yearbook of China). Beijing: Zhongguo tongji chubanshe, various years.

Terrill, Ross. The New Chinese Empire: And What It Means for the United States. Basic Books, 2003.

Timperlake, Edward, and William C. Triplett, II. Red Dragon Rising: Communist China's Military Threat to America. Washington, D.C.: Regnery Publishing, 2002.

Wang Yan and Yao Yudong. "Sources of China's Economic Growth 1952-1999: Incorporating Human Capital Accumulation." China Economic Review 14, no. 1 (2003): $32-52$.

World Bank Development Indicators. Cross-country database at http://www.worldbank.org/data.

World Bank. China 2020. Washington, D.C.: World Bank, 1997.

Woo, Wing Thye. The Art of Reforming Centrally Planned Economies: Comparing China, Poland, and Russia." Journal of Comparative Economics 18, no. 3 (June 1994): 276-308. 137.

“The Real Reasons for China's Growth." The China Journal, no. 41 (Jan. 1999): 115-

Wu Yanrui. China's Economic Growth: A Miracle with Chinese Characteristics. London and New York: RoutledgeCurzon, 2004.

Young, Alwyn. "Gold into Base Metals: Productivity Growth in the People's Republic of China during the Reform Period.” Journal of Political Economy 111, no. 6 (Dec. 2003): 1220-61.

Zeng, Ming, and Peter J. Williamson. "The Hidden Dragons." Harvard Business Review, October 2003: 92-99. 
Table 1. First Year in Which China's GDP Exceeds U.S. GDP

\begin{tabular}{lcrrrr}
\hline & Price adjustment? & Aggregate & \multicolumn{3}{c}{ Per capita GDP } \\
& Exchange rate adjustment? & GDP & National & China coast & China 5 prov. \\
\hline 1. & U.S. price level = 3.86 * PRC price level & 2011 & 2035 & 2024 & 2021 \\
2. & $+3 \%$ annual RMB appreciation & 2009 & 2026 & 2019 & 2017 \\
3. & U.S. price level = 3 * PRC price level & 2015 & 2040 & 2027 & 2023 \\
4. & + + 3\% annual RMB appreciation & 2012 & 2029 & 2021 & 2019 \\
5. & No price adjustment & 2033 & 2057 & 2041 & 2036 \\
6. & $+3 \%$ annual RMB appreciation & 2024 & 2041 & 2031 & 2028 \\
\hline
\end{tabular}

Base year for the projections is 2005 . Annual growth rates used in the projections are the average annual real growth rates of China and the U.S. in 1978-2005. The price adjustment factor of 3.86 is that of 2004, the most recent year for which the PWT 6.2 provides data. (The values of 2000-04 are: $4.217306,4.223668,4.264024,4.186857,3.859263$.)

"China coast" refers to the coastal provinces of China (in comparison to the national average in the U.S.); it includes Beijing, Tianjin, Hebei, Liaoning, Shanghai, Jiangsu, Zhejiang, Fujian, Shandong, Guangdong, and Guangxi (the small province Hainan was omitted due to a lack of data for 1978 when Hainan was part of Guangdong province). "China 5 prov." refers to the five fastestgrowing coastal provinces in China (Jiangsu, Zhejiang, Fujian, Shandong, Guangdong). The share of the coast in China's population in mid-2005 is $42.5 \%$, and in annual GDP $66.2 \%$; the corresponding shares of the five provinces are $25.9 \%$ and $43.3 \%$.

Nominal and real GDP values of 1978 and 2005 are those published by the National Bureau of Statistics in China and by the Bureau of Economic Analysis in the U.S. Per capita GDP values are obtained by dividing aggregate GDP by the midyear population. U.S. population data for the year 2005 is the official estimate. Chinese provincial-level population data of 1978 are based on the 1 July 1982 and the 1 November 2000 censuses, with mid-1978 values obtained by extrapolation using the implicit average annual population growth rate of 1982-2000.

The average annual real growth rate of economy-wide GDP in China in 1978-2005 is 9.6358\%; in the U.S., it is $2.9687 \%$. The average annual growth rate of real GDP per capita in China is $8.3840 \%$, and in the U.S. $1.8821 \%$. The average annual population growth rate in China is $1.1549 \%$ and in the U.S. $1.0665 \%$. The average exchange rate in 2005 is 8.1917 yuan RMB/USD.

Sources: PWT 6.2. Census 2000 Major Figures, pp. 16, 31. Statistical Yearbook 1991, p. 79; 2006, pp.

57, 60, 99, 734. Bureau of Economic Analysis, at http://www.bea.gov/bea/dn/home/gdp.htm (choose "Current-dollar and "real" GDP, XLS;" accessed on 30 Nov. 06). Population data from http://www.census.gov/popest/archives/1990s/popclockest.txt and for 2000-05 from

http://www.census.gov/popest/states/NST-ann-est.html (both accessed on 30 Nov. 06). 


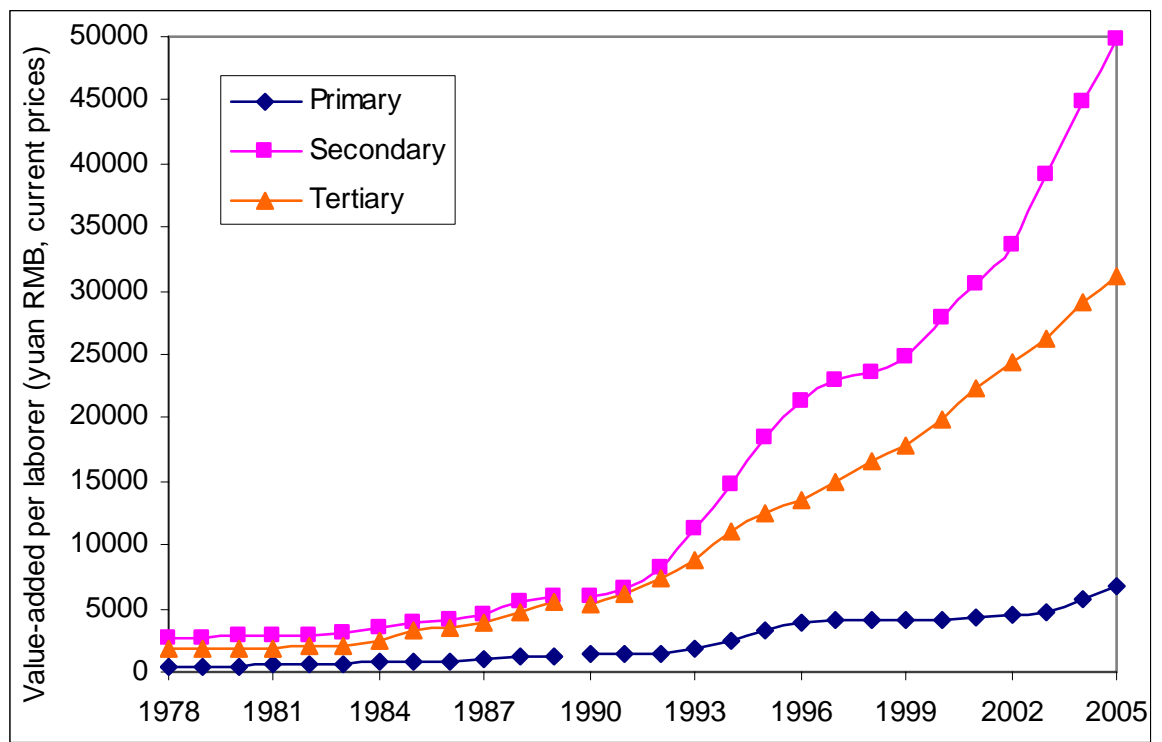

Employment data are midyear values (as average of end-year values). All employment data (sectoral, total) between 1989 and 1990 experience a statistical break; end-year 1990 total employment exceeds that of 1989 by $17.03 \%$. Official (unadjusted) employment data are used. The secondary sector comprises industry and construction.

\section{Figure 1. Sectoral Labor Productivity in China}

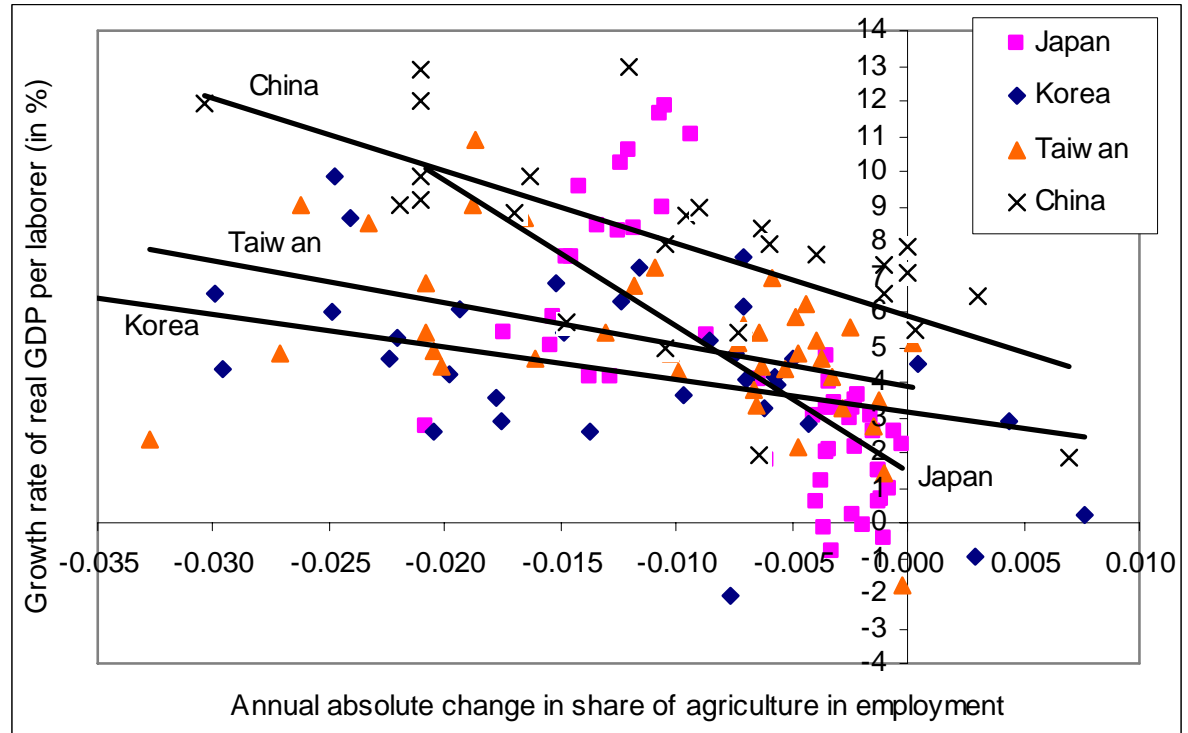

Japan 1956-2005, Korea 1971-2005, Taiwan 1967-2005, and China 1979-2005 (except 1990). Annual absolute change in share of agriculture in employment is based on end-year employment values, while the growth rate of real GDP per laborer is based on average (or, in the case of China, midyear) employment values.

Two data points are omitted in order to keep the chart compact: Korea $1972(0.0224,0.9448)$ and $1998(0.0125,-4.6146)$.

Figure 2. Structural Change and Labor Productivity Growth 


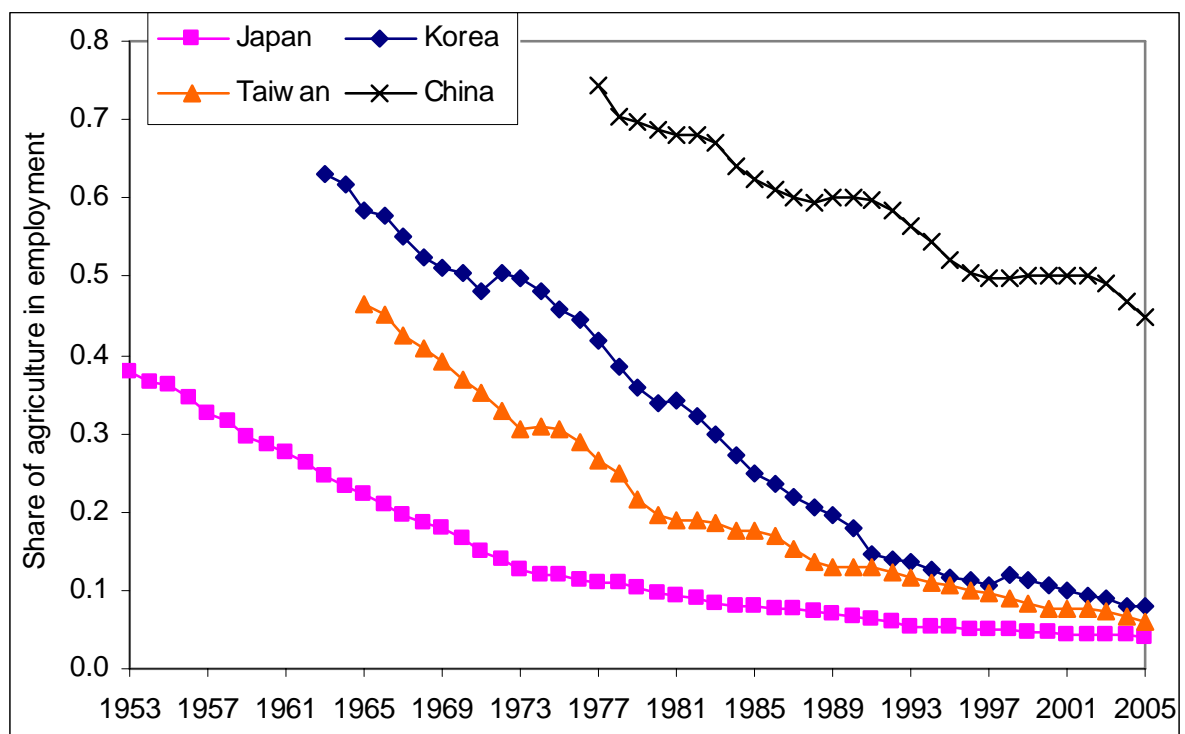

Employment data are average annual values (in the case of China, midyear values). Values for Japan only comprise agriculture (presumably farming and animal husbandry) and forestry; they exclude fishery due to a lack of time series data.

Figure 3. Share of Agricultural Laborers in Economy-wide Employment

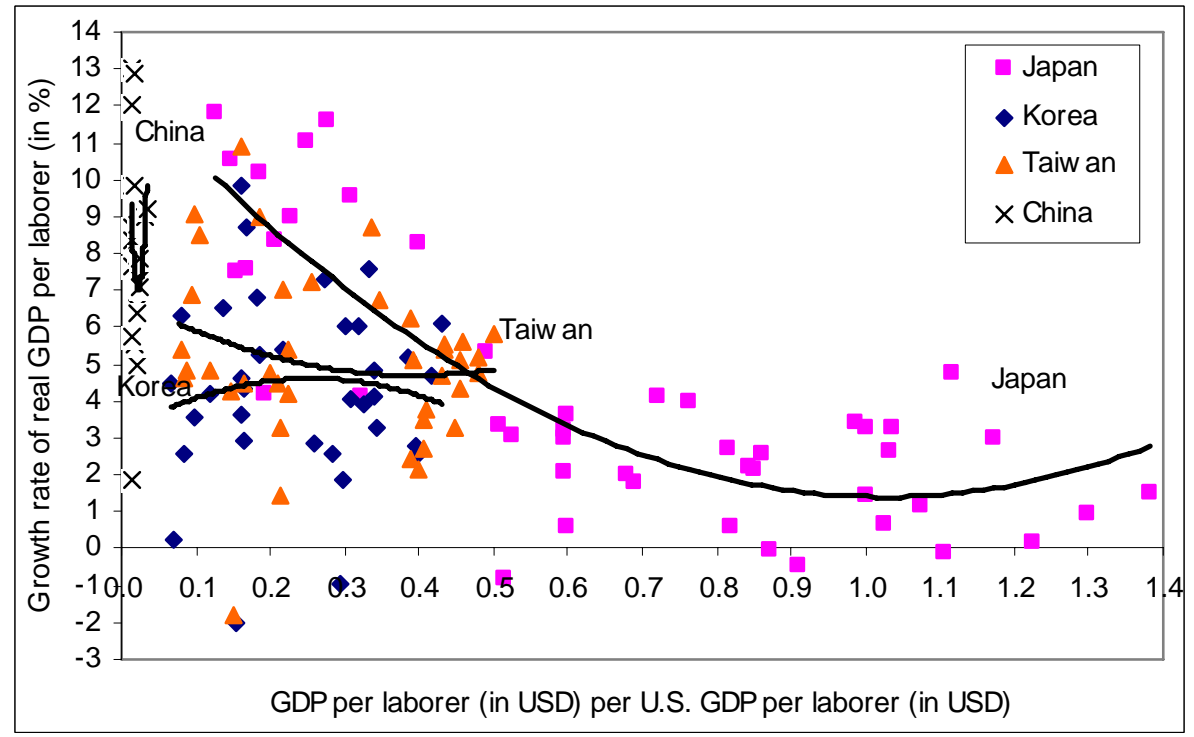

Japan 1960-2005, Korea 1971-2005, Taiwan 1967-2005, and China 1979-2005 (except 1990).

Figure 4. Catching Up and Labor Productivity Growth 


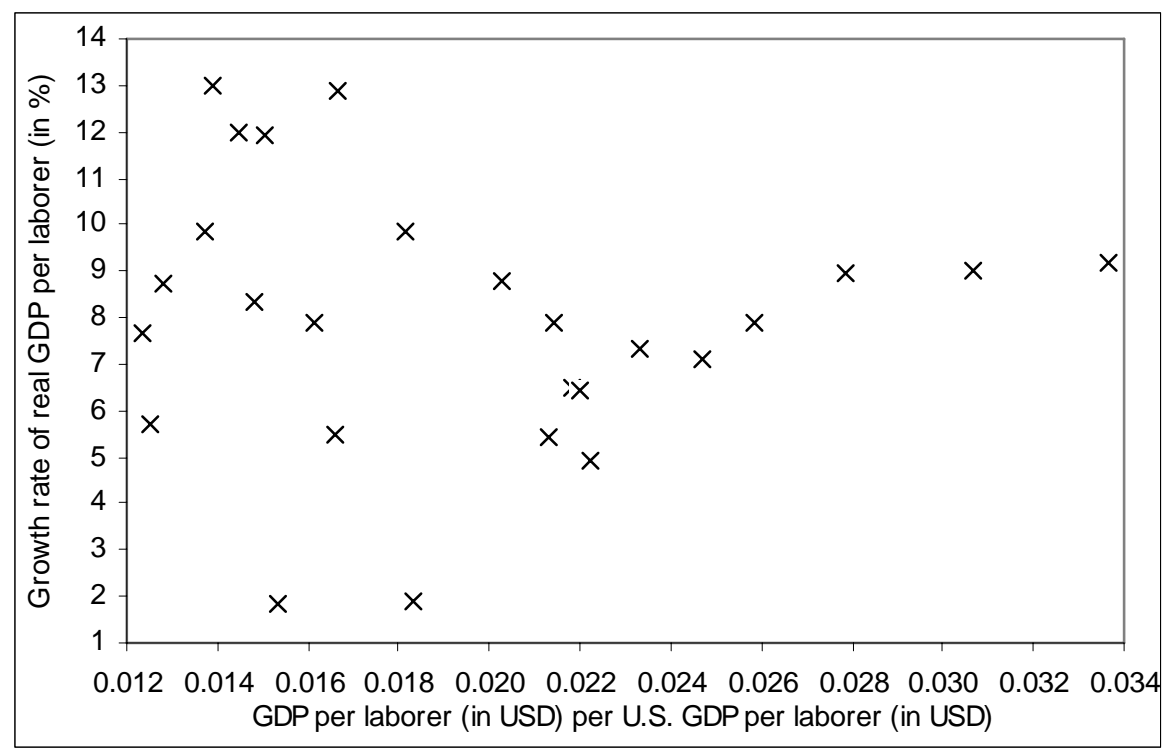

For period covered see previous figure.

Figure 5. Catching Up and Labor Productivity Growth in China, 1979-2002

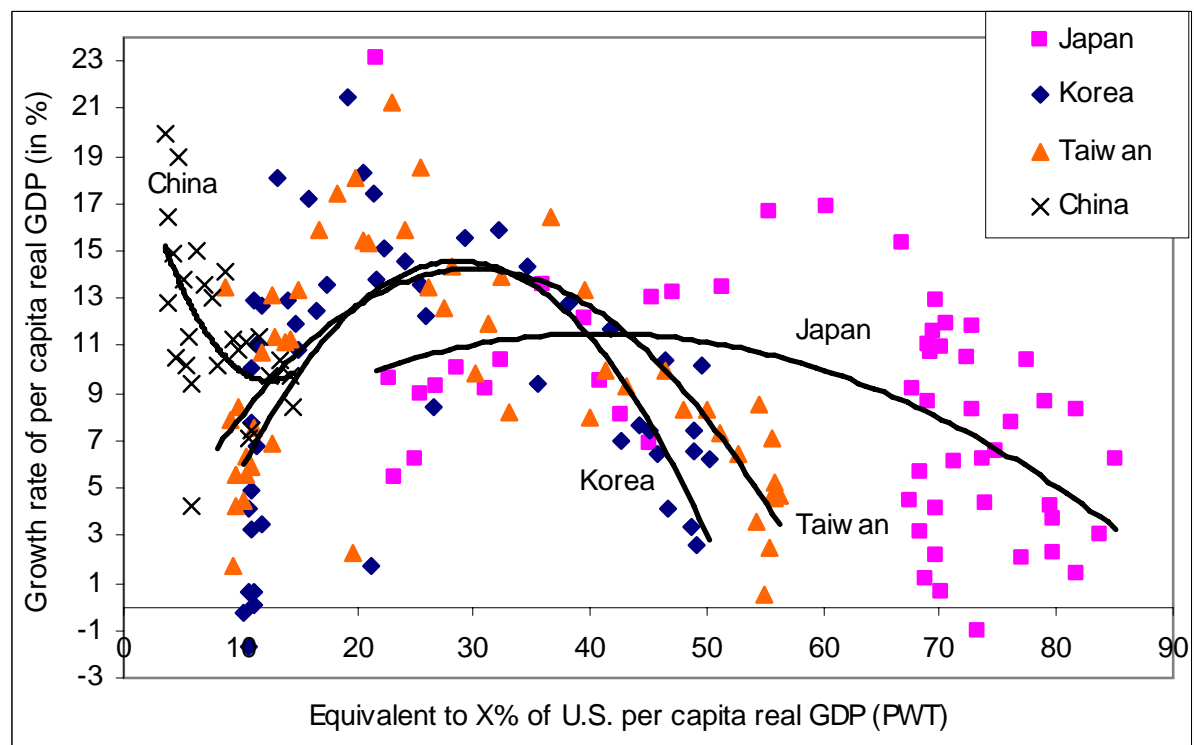

All data are PWT 6.2 data; only per capita data are available (population productivity growth). The data (following PWT data availability) cover the following periods: Japan 1951-2004, Korea 1954-2004, Taiwan 1952-2004, and China 1979-2004.

One data point is omitted in order to keep the chart compact: Korea $1998(43.95,-6.52)$.

Figure 6. Catching Up and Labor Productivity Growth (PPP-adjusted per capita data), 1950s-1990s 


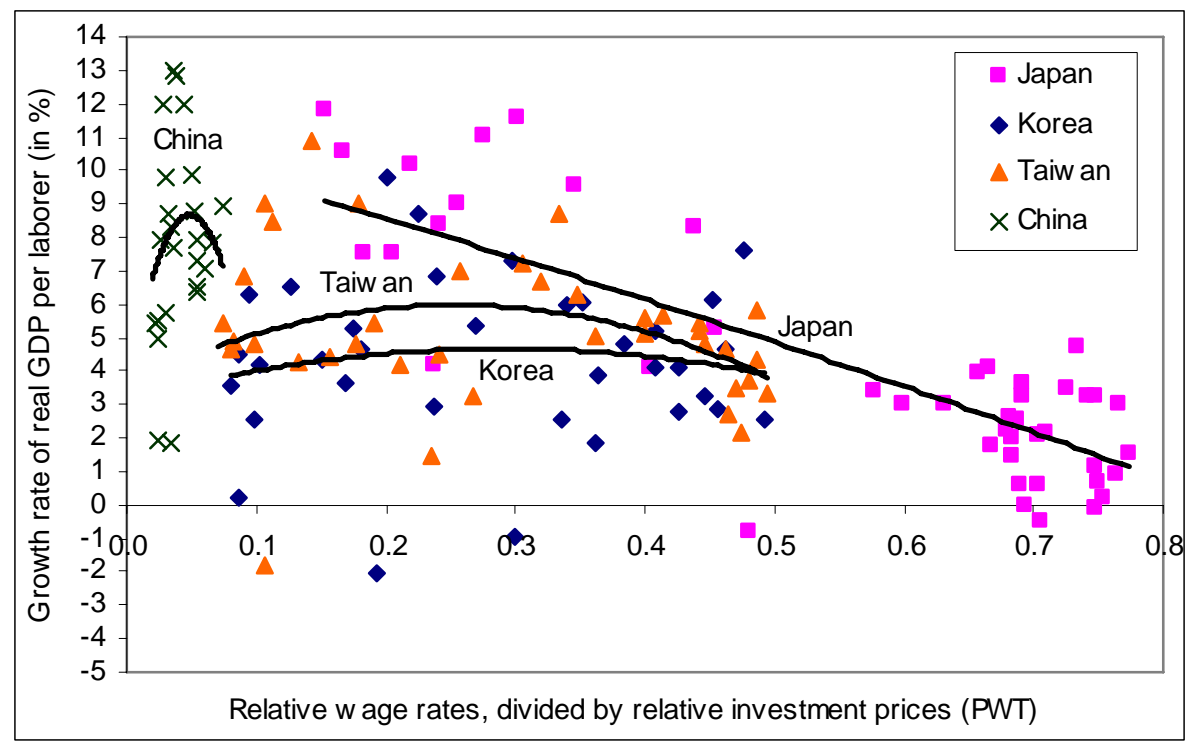

Japan 1960-2004, Korea 1971-2004, Taiwan 1967-2004, and China 1979-2004 (except 1990 due to a statistical break in the employment series, and except 2004 due to a lack of income approach GDP data [with the component labor remuneration, needed to derive wages]). The relative investment prices (only) are from the PWT, with as final year for which data are available 2004.

Wages and investment prices are relative to the U.S.

\section{Figure 7. Relative Factor Price Equalization and Labor Productivity Growth}

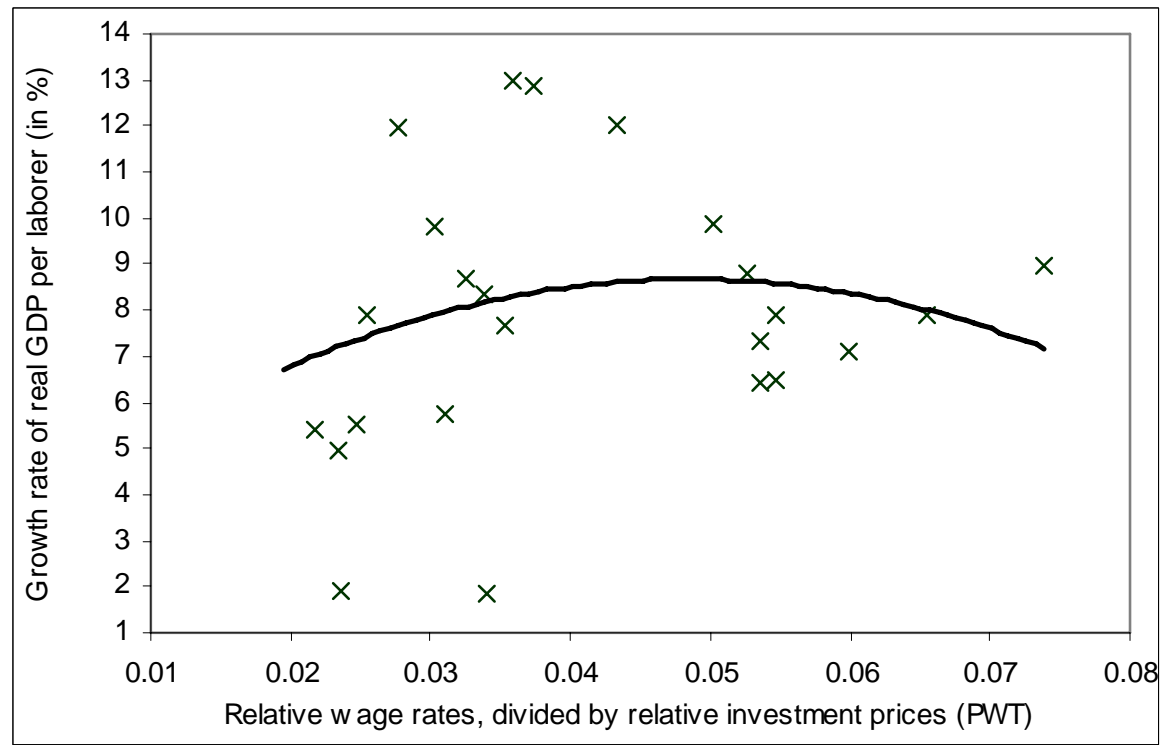

Wages and investment prices are relative to the U.S. For period covered see previous figure.

Figure 8. Relative Factor Price Equalization and Labor Productivity Growth in China, 1979-2000 
Table 2. Data 1978-2003

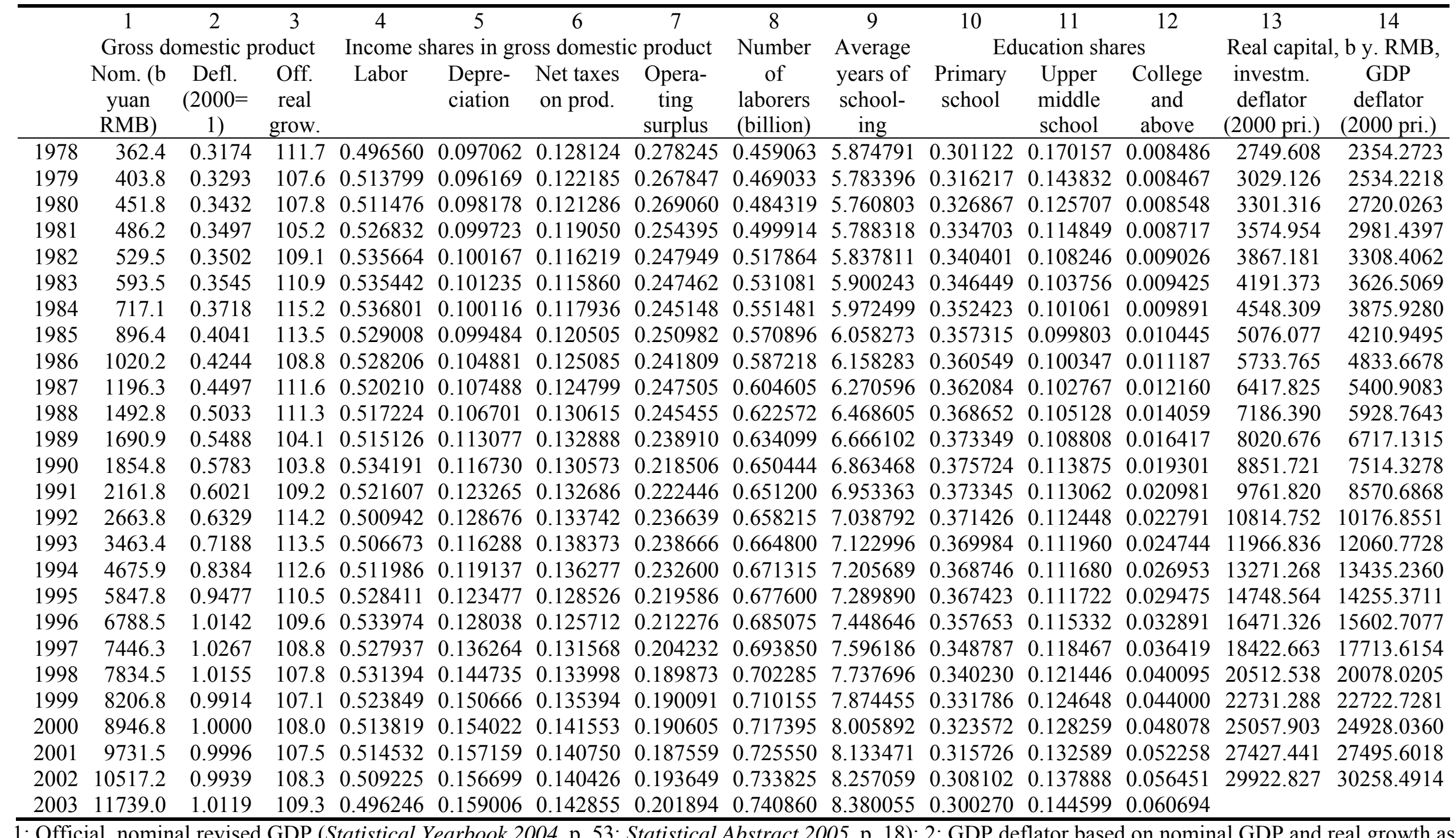

first published (Statistical Yearbook series; "first published" relevant for years since 1988); 3: Official real GDP growth rate (Statistical Yearbook 2004, p. 55); 4-7: for sources see note 29; 8-12: (i) laborers and education data include military personnel, (ii) education shares denote the share of laborers with this level of education as highest level of education (source: Carsten Holz, 2005); 13: Capital data, deflated using the investment deflator (Carsten Holz, 2006b, data using investment-based scrap rates); 14: Capital data, deflated using the GDP deflator of column 2 (original nominal data from appendix "Fixed Asset Data" to Carsten Holz, 2006b). Nominal wages can be obtained as (columns) $4 * 1 / 8$. 
Table 3. Projections of the Quantity and Quality of Labor, 2000-2025

\begin{tabular}{lccccc}
\hline & $\begin{array}{c}\text { Number } \\
\text { of laborers } \\
\text { (billion) }\end{array}$ & $\begin{array}{c}\text { Average } \\
\text { years of } \\
\text { schooling }\end{array}$ & $\begin{array}{c}\text { Primary } \\
\text { school }\end{array}$ & $\begin{array}{c}\text { Education shares } \\
\text { middle } \\
\text { school }\end{array}$ & $\begin{array}{c}\text { College and } \\
\text { above }\end{array}$ \\
\hline 2000 & 0.714409 & 8.012866 & 0.322023 & 0.128666 & 0.047978 \\
2001 & 0.720456 & 8.121377 & 0.316476 & 0.132001 & 0.049943 \\
2002 & 0.726477 & 8.225262 & 0.310170 & 0.135132 & 0.052176 \\
2003 & 0.732213 & 8.328351 & 0.303293 & 0.138031 & 0.054809 \\
2004 & 0.738277 & 8.429856 & 0.295426 & 0.140944 & 0.057955 \\
2005 & 0.744419 & 8.525540 & 0.290574 & 0.144071 & 0.061807 \\
2006 & 0.748436 & 8.630268 & 0.283859 & 0.147869 & 0.066709 \\
2007 & 0.753146 & 8.739400 & 0.276419 & 0.152366 & 0.072457 \\
2008 & 0.759109 & 8.853824 & 0.268099 & 0.157413 & 0.078968 \\
2009 & 0.765298 & 8.971423 & 0.259523 & 0.162841 & 0.086169 \\
2010 & 0.771226 & 9.087972 & 0.250992 & 0.168101 & 0.093810 \\
2011 & 0.775696 & 9.204913 & 0.242083 & 0.172995 & 0.101810 \\
2012 & 0.778933 & 9.319190 & 0.233075 & 0.177402 & 0.109984 \\
2013 & 0.780788 & 9.432353 & 0.223856 & 0.181429 & 0.118242 \\
2014 & 0.780522 & 9.547423 & 0.214194 & 0.185377 & 0.126681 \\
2015 & 0.779117 & 9.663950 & 0.204020 & 0.189114 & 0.135212 \\
2016 & 0.776259 & 9.781167 & 0.193563 & 0.192779 & 0.143936 \\
2017 & 0.771466 & 9.902992 & 0.182228 & 0.196412 & 0.152955 \\
2018 & 0.765336 & 10.026827 & 0.170430 & 0.199982 & 0.162217 \\
2019 & 0.757166 & 10.158197 & 0.157691 & 0.204050 & 0.171948 \\
2020 & 0.748612 & 10.291379 & 0.144724 & 0.208449 & 0.181854 \\
2021 & 0.740170 & 10.422555 & 0.132106 & 0.212959 & 0.191815 \\
2022 & 0.733109 & 10.546202 & 0.120267 & 0.217183 & 0.201424 \\
2023 & 0.728962 & 10.655325 & 0.109798 & 0.220659 & 0.210190 \\
2024 & 0.727125 & 10.749938 & 0.101092 & 0.223477 & 0.218290 \\
2025 & 0.725704 & 10.838512 & 0.093474 & 0.226045 & 0.226240 \\
\hline Datan
\end{tabular}

Data are from Carsten Holz (2005). Values for 2000-03 differ slightly from those in Table 2 due to (by necessity) different procedures used in the construction of the two sets of data. Each set of data is consistent individually. 


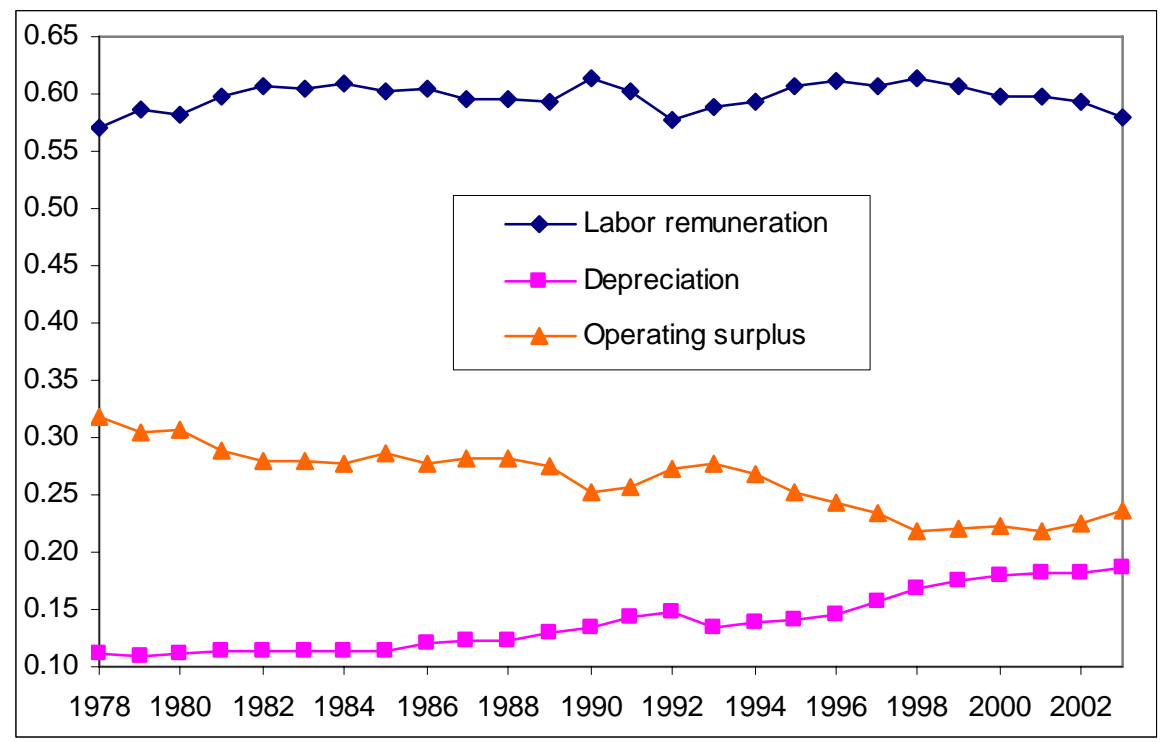

The values of all income components are by necessity derived from provincial-level data published in GDP 1952-95, GDP 1996-2002, and for the years since the mid-1990s in the corresponding year's Statistical Yearbook. For each year, the share of each income component in 'GDP less net taxes on production' is obtained as the sum across provinces of the values of a particular income component divided by the sum across provinces of 'GDP less net taxes on production.'

Figure 9. Income Factor Shares in ‘GDP Less Net Taxes on Production,’ 1978-2003

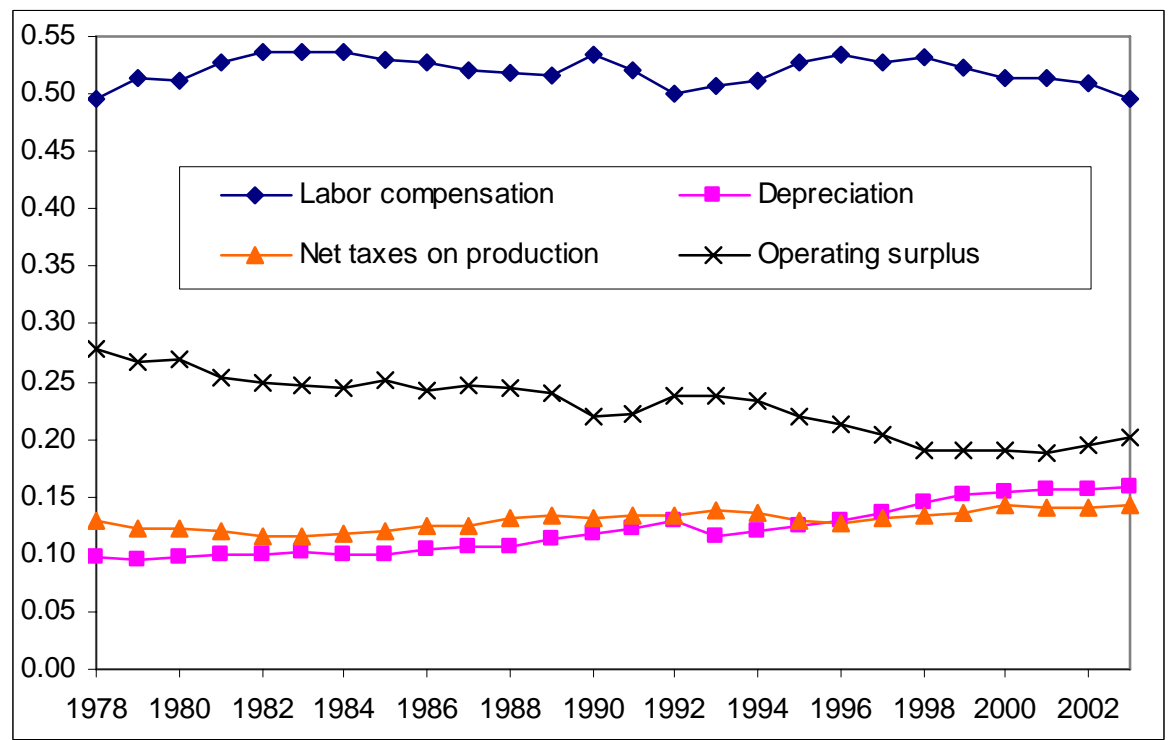

For notes see previous figure.

\section{Figure 10. Income Factor Shares in GDP}


Table 4. Cointegration Equations, 1978-2002/03

\begin{tabular}{|c|c|c|c|c|}
\hline "Dependent" variable & All variable & in levels & All variables in $n$ & al logarithms \\
\hline Regression number & $\begin{array}{l}\text { A. Wage } \\
\text { I }\end{array}$ & $\begin{array}{l}\text { B. Capital } \\
\text { II }\end{array}$ & $\begin{array}{l}\text { A. Wage } \\
\text { III }\end{array}$ & $\begin{array}{l}\text { B. Capital } \\
\text { IV }\end{array}$ \\
\hline Constant & 4387.96 & 4144.38 & 6.2426 & 7.6163 \\
\hline $\begin{array}{l}\text { C. Average years of schooling } \\
\text { minus } 5\end{array}$ & & & $\begin{array}{r}0.7171 \\
(12.8369)\end{array}$ & $\begin{array}{r}0.2829 \\
(3.1779)\end{array}$ \\
\hline $\begin{array}{l}\text { D. Average years of schooling } \\
\text { minus } 5 \text {, squared }\end{array}$ & & $\begin{array}{r}3126.44 \\
(23.1977)\end{array}$ & & \\
\hline $\begin{array}{l}\text { E. Share of laborers with } \\
\text { primary school education }\end{array}$ & & & $\begin{array}{r}-1.3593 \\
(-5.0228)\end{array}$ & \\
\hline $\begin{array}{l}\text { F. Share of laborers with upper } \\
\text { middle school education }\end{array}$ & $\begin{array}{r}-39066.18 \\
(-4.0676)\end{array}$ & & & \\
\hline $\begin{array}{l}\text { G. Share of laborers with } \\
\text { college level education or } \\
\text { above }\end{array}$ & $\begin{array}{r}152080.0 \\
(18.8042)\end{array}$ & & & \\
\hline H. Number of laborers & & $\begin{array}{r}-13973.42 \\
(-2.5510)\end{array}$ & & \\
\hline I. Trend & & $\begin{array}{r}238.63 \\
(2.3934) \\
\end{array}$ & & $\begin{array}{r}0.0946 \\
(15.2316) \\
\end{array}$ \\
\hline Lag length of the VEC & 2 & 2 & 1 & 2 \\
\hline Trace, maximum eigenvalue test & $1 \%, 5 \%$ & $1 \%, 1 \%$ & $1 \%, 1 \%$ & $5 \%, 5 \%$ \\
\hline Normality (10\% level) & OK & $\mathrm{OK}$ & C $1 \%$, E $10 \%$ & OK \\
\hline Granger causality "Y: X (Z\%)" & None & $\mathrm{H}: \mathrm{D}(10)$ & $\begin{array}{r}\text { A: } \mathrm{E}(0.1) \\
\mathrm{C}: \mathrm{E}(5) \\
\end{array}$ & $\mathrm{B}: \mathrm{I}(1)$ \\
\hline $\begin{array}{l}\text { Variance decomposition } \\
\quad \text { period } 3\end{array}$ & $\begin{array}{r}\text { A: } 97 / 1 / 2 \\
\text { F: } 34 / 66 / 0 \\
\text { G: } 1 / 78 / 21\end{array}$ & $\begin{array}{l}\text { B: } 87 / 11 / 2 \\
\text { D: } 19 / 77 / 5 \\
\text { H: } 83 / 1 / 17\end{array}$ & $\begin{array}{r}\text { A: } 82 / 3 / 15 \\
\text { C: } 0 / 94 / 6 \\
\text { D: } 0 / 61 / 38\end{array}$ & $\begin{array}{r}\text { B: } 87 / 13 \\
\text { C: } 8 / 92\end{array}$ \\
\hline $\begin{array}{l}\text { Variance decomposition } \\
\text { period } 10\end{array}$ & $\begin{array}{r}\text { A: } 66 / 12 / 22 \\
\text { F: } 16 / 81 / 3 \\
\text { G: } 19 / 60 / 21\end{array}$ & $\begin{array}{r}\text { B: } 25 / 70 / 5 \\
\text { D: } 23 / 72 / 5 \\
\text { H: } 33 / 45 / 22\end{array}$ & $\begin{array}{r}\text { A: } 65 / 4 / 31 \\
\mathrm{C}: 11 / 89 / 10 \\
\mathrm{E}: 13 / 60 / 27\end{array}$ & $\begin{array}{r}\text { B: } 29 / 71 \\
\text { C: } 6 / 94\end{array}$ \\
\hline Number of observations & 23 & 22 & 24 & 22 \\
\hline
\end{tabular}

Wage per laborer: labor compensation in the national income accounts divided by the number of laborers including military personnel (in yuan per laborer); deflated by the GDP deflator (in 2000 prices).

Capital: measure of capital's contribution to production, in billion yuan, deflated by the GDP deflator (in 2000 prices).

Number of laborers is in billion.

Values in parentheses underneath coefficient estimates are t-values.

Trend: the cointegrating vector (as does the VAR) always includes a constant; depending on the results of the trace test and the maximum eigenvalue test, a trend is included or not.

Trace, maximum eigenvalue test: significance level of the existence of one eigenvector.

Normality in VEC equations: Jarque-Bera values are used (based on Cholesky (Lutkepohl) orthogonalization). When normality is rejected for one of the VEC equations at the $10 \%$ level, the significance level is stated together with a letter which identified the variable that, in first differences, is the dependent variable of the particular equation.

Granger causality "Y: $\mathrm{X}(\mathrm{Z} \%)$ " means that "Y is Granger-caused by $\mathrm{X}$ (at the $0.1,1,5$, or $10 \%$ significance level)."

Variance decomposition: a Cholesky ordering of variables as listed above in the particular table column was used, and the forecast error variance decomposed annually over a period of 10 years. Values are percentages, ordered as the variables appear in the column. For example, if the three variables involved are $\mathrm{A}, \mathrm{C}$, and $\mathrm{D}$, and the variance concerned is that of $\mathrm{A}$, then $\mathrm{A} / \mathrm{C} / \mathrm{D} \%$ of the variance of $\mathrm{A}$ is explained by variation in $\mathrm{A}, \mathrm{C}$, and $\mathrm{D}$. Percentages may not add up to 100 due to rounding. 
Table 5. Growth Forecasts (average annual growth rates in \%)

\begin{tabular}{|c|c|c|c|c|c|c|c|c|c|}
\hline & \multicolumn{5}{|c|}{ Individual variables } & \multicolumn{4}{|c|}{ GDP } \\
\hline & \multirow[t]{2}{*}{$\begin{array}{l}\text { Wage } \\
\text { (I) }\end{array}$} & \multirow[t]{2}{*}{$\begin{array}{l}\text { Capital } \\
\text { (II) }\end{array}$} & \multirow[t]{2}{*}{$\begin{array}{l}\text { Wage } \\
\text { (III) }\end{array}$} & \multirow[t]{2}{*}{$\begin{array}{l}\text { Capital } \\
\text { (IV) }\end{array}$} & \multirow[t]{2}{*}{ Labor } & \multicolumn{2}{|c|}{ Equation (2) } & \multicolumn{2}{|c|}{$\begin{array}{l}\text { Labor share } \\
\text { assumed fixed }\end{array}$} \\
\hline & & & & & & $\mathrm{I}+\mathrm{II}$ & III+IV & I & III \\
\hline $2000-05$ & 4.15 & 6.98 & 5.18 & 10.91 & 0.83 & 5.80 & 8.09 & 4.98 & 6.05 \\
\hline $2005-10$ & 8.18 & 6.37 & 6.29 & 10.85 & 0.71 & 7.84 & 8.83 & 8.89 & 7.05 \\
\hline 2010-15 & 7.76 & 5.63 & 7.81 & 10.75 & 0.20 & 7.06 & 9.42 & 7.96 & 8.03 \\
\hline 2015-20 & 6.36 & 5.40 & 11.79 & 10.71 & -0.80 & 5.50 & 10.85 & 5.56 & 10.90 \\
\hline $2020-25$ & 4.63 & 4.14 & 14.22 & 10.54 & -0.62 & 4.06 & 12.02 & 4.01 & 13.51 \\
\hline $2000-25$ & 6.20 & 5.70 & 9.01 & 10.75 & 0.06 & 6.05 & 9.83 & 6.26 & 9.07 \\
\hline $\begin{array}{l}\text { Cumulative: } \\
2000-25\end{array}$ & 350.04 & 299.69 & 763.49 & 1184.75 & 1.58 & 333.77 & 942.78 & 356.58 & 777.14 \\
\hline
\end{tabular}

The numbers I - IV refer to the previous table. All calculations are done annually before averaging to five-year or 25-year values. The antilogarithm was applied to the annual forecast values of the wage rate (III) and capital (IV) before calculating growth rates.

GDP calculated via the definition of the labor share, with an assumed fixed labor share (of 0.5138 , year 2000) in GDP including net taxes on production, uses one of the two wage series plus the labor series.

GDP calculated using equation (2), in addition, uses one of the two capital series; the depreciation rate, surplus rate, and net tax rate on production are assumed constant and therefore do not enter into the calculation. Equation (2) reduces to

$$
\hat{Y}_{t}^{\tau} \equiv a_{t}^{\tau}\left[\left(\frac{\hat{w}_{t}}{P_{t}}\right)+\hat{L}_{t}\right]+\left(d_{t}^{\tau}+e_{t}^{\tau}\right)\left(\frac{\hat{K}_{t}^{P}}{P_{t}}\right)=a_{t}^{\tau}\left[\left(\frac{\hat{w}_{t}}{P_{t}}\right)+\hat{L}_{t}\right]+\left(1-a_{t}^{\tau}\right)\left(\frac{\hat{K}_{t}^{P}}{P_{t}}\right) .
$$

When calculating the year 2001 GDP growth rate, the actual year 2000 labor share in GDP less net taxes on production (0.5985) is used to weight the 2001 (over 2000) growth rates of the real wage rate, labor, and real capital. When calculating the year 2002 GDP growth rate, the year 2001 labor share is used; the 2001 labor share is calculated using the actual year 2000 real wage rate augmented by its fitted 2001 growth rate, the forecast labor value of 2001, and the actual year 2000 GDP value augmented by its 2001 growth rate derived in the previous step. The same step-by-step procedure is used for the following years. Using variables I+II, the minimum labor share in the period 2000-2025 is 0.5741 , the maximum labor share 0.6336 ; using variables III+IV, the two values are 0.4615 and 0.5961 .

For comparison, the average annual GDP growth rate in $1978-2003$ was $9.37 \%$ (using the official real GDP growth rates) or $9.72 \%$ using the latest revised nominal GDP data combined with the first published, implicit GDP deflator; the cumulative growth rate is $839.29 \%$ and $915.96 \%$. 
Table 6. Educational Level (or Higher) of Population Age 25 or Older (Census Data)

\begin{tabular}{|c|c|c|c|c|c|}
\hline \multirow[b]{2}{*}{ This degree or above } & \multicolumn{2}{|c|}{ in $\%$} & \multicolumn{2}{|c|}{ Absolute number (mio.) } & \multirow{2}{*}{$\begin{array}{c}\text { Ratio US/ } \\
\text { China }\end{array}$} \\
\hline & US & China & US & China & \\
\hline & \multicolumn{5}{|c|}{2000} \\
\hline High school & 80.4 & 16.5 & 146.498 & 125.137 & 1.17 \\
\hline Some college & 51.8 & & 94.386 & & \\
\hline College-level associate degree & & 4.3 & & 32.457 & 2.91 \\
\hline Bachelor's degree & 24.4 & 1.4 & 44.460 & 10.258 & 4.33 \\
\hline Advanced degree & 8.9 & 0.1 & 16.217 & 0.757 & 21.42 \\
\hline \multicolumn{6}{|l|}{ Reference: total population age } \\
\hline \multirow[t]{2}{*}{25 or higher } & & & 182.212 & 760.480 & 0.24 \\
\hline & \multicolumn{5}{|c|}{1990} \\
\hline High school & 75.2 & 9.52 & 119.469 & 72.421 & 1.65 \\
\hline Some college & 45.2 & & 71.809 & & ) \\
\hline College-level associate degree & & 1.51 & & 11.517 & 6.24 \\
\hline Bachelor's degree & 20.3 & 0.56 & 32.250 & 4.249 & 7.59 \\
\hline Advanced degree & 7.2 & n.a. & 11.439 & n.a. & n.a. \\
\hline Reference: total population age & & & & & \\
\hline 25 or higher & & & 158.868 & 571.589 & 0.28 \\
\hline
\end{tabular}

For the classification see an appendix. Advanced degree holders in the U.S. refers to the three degrees above B.A., in China to Master's or Doctorate degree holders. No data on advanced degree holders in China for 1990 are available. If Bachelor's degree and above in the case of the U.S. were compared to College-level associate degree and above in China, the ratio of the U.S. to China in 1990 is $2.80(32.250 / 11.517)$, and in 2000 it is $1.37(44.460 / 32.457)$.

U.S. data report degree obtained, while Chinese data include those who have already obtained the particular degree as well as those who are currently studying for the particular degree. Since the U.S. age classification is limited to those age 25 and older (and the Chinese classification has been reduced here to the U.S. classification), the number of Chinese who are currently studying towards a particular degree should be small, except possibly in the case of advanced degrees.

Sources: U.S.: Educational Attainment 2000. China: Census 2000, pp. 593-602; Census 1990, Vol. 1, p. 380, Vol. 2, pp. 112f. and 132f.

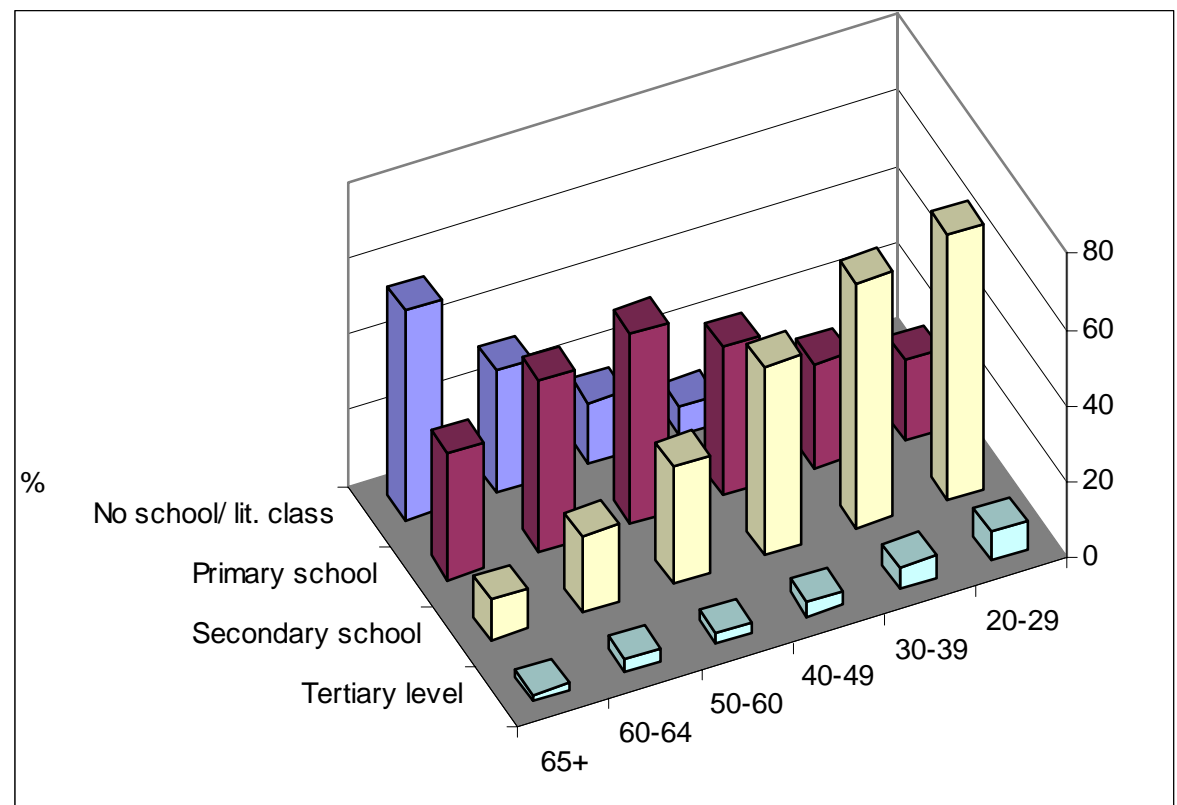

"No school/ lit. class" refers to no schooling or only basic literacy class (below primary school level). Source: Census 2000 (nationality), pp. 125-7.

Figure 11. Share of Educational Level in Individual Age Groups, China, 2000 (in \%) 


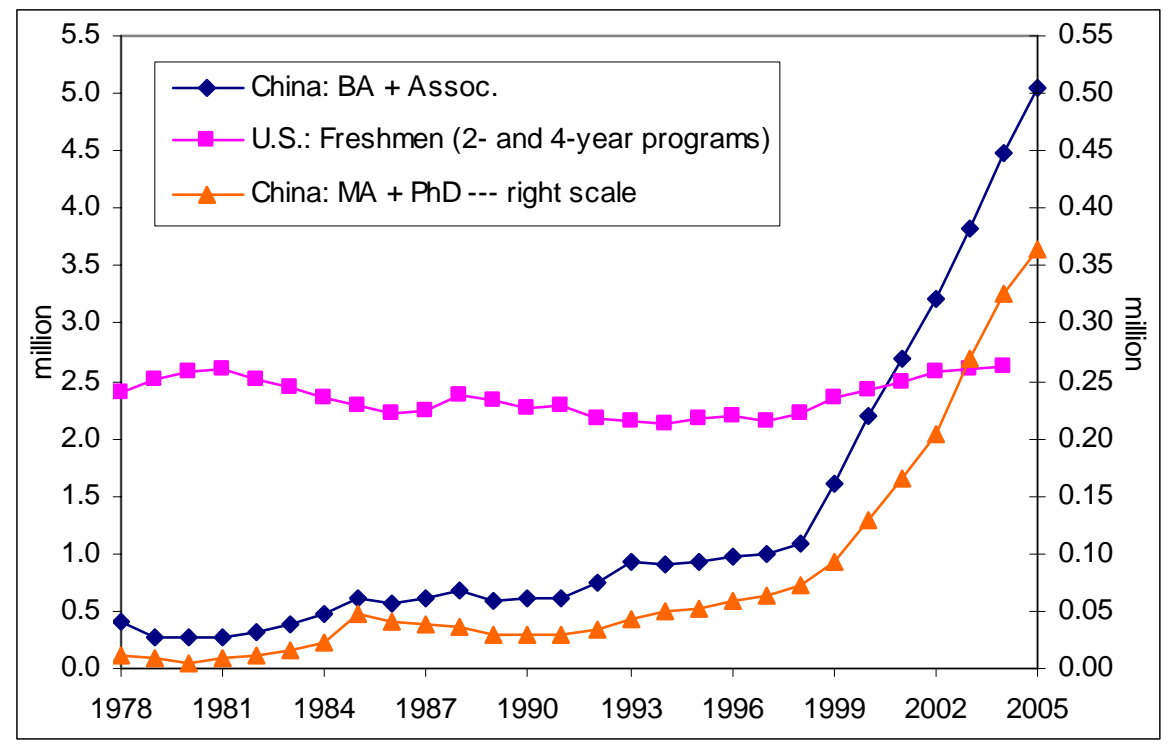

"BA" in the case of China refers to (current-year) new enrollment in regular institutions of higher education, i.e., includes BA and college-level associate degree programs of regular institutions of higher education; no data on new enrollment in college-level associate degree programs of "nonregular" institutions of higher education are available. For the U.S., only data on "first-time freshmen" are available; the coverage is unclear, but seems to be 2-year and 4-year programs, presumably associate and BA programs, and possibly including professional degree programs. Stable graduation figures in U.S. MA/PhD programs suggest new enrollment in these programs of at least 400,000 to 500,000 per year (assuming no drop-outs).

In China, in 2005, 54.35\% of total enrollment in regular institutions of higher education was in regular BA programs (benke), while the rest was in college-level associate degree programs (zhuanke); but only $46.86 \%$ of new enrollment in regular institutions of higher education was in regular BA programs. In the U.S., in 2004, the latest year for which the data are available, $62.10 \%$ of total fall enrollment in degree-granting institutions was in 4-year (vs. 2-year) programs, and 56.54\% of total first-time freshmen enrollment in undergraduate programs was in 4-year programs.

Data for the U.S. for the years through 1995 cover "institutions of higher education," and since 1996 "degree-granting institutions" (which include some additional institutions, primarily 2-year colleges, and exclude a few higher education institutions that did not award associate or higher degrees); for first-time freshmen enrollment, both sets of data are available for 1996 and 1997: data in the latter classification are 3-4 percentage points larger than the data in the earlier classification. Sources:

China: Statistical Yearbook 1990, pp. 708f.; 2003, pp. 720f.; 2004, pp. 780-2; 2005, pp. 692f.; 2006, pp. 798, 800f..

U.S.: http://nces.ed.gov/programs/digest/d05/tables/dt05_179.asp, and .../dt195.asp, accessed on 15 Nov. 2006.

Figure 12. Tertiary Level New Enrollment, China and U.S. 


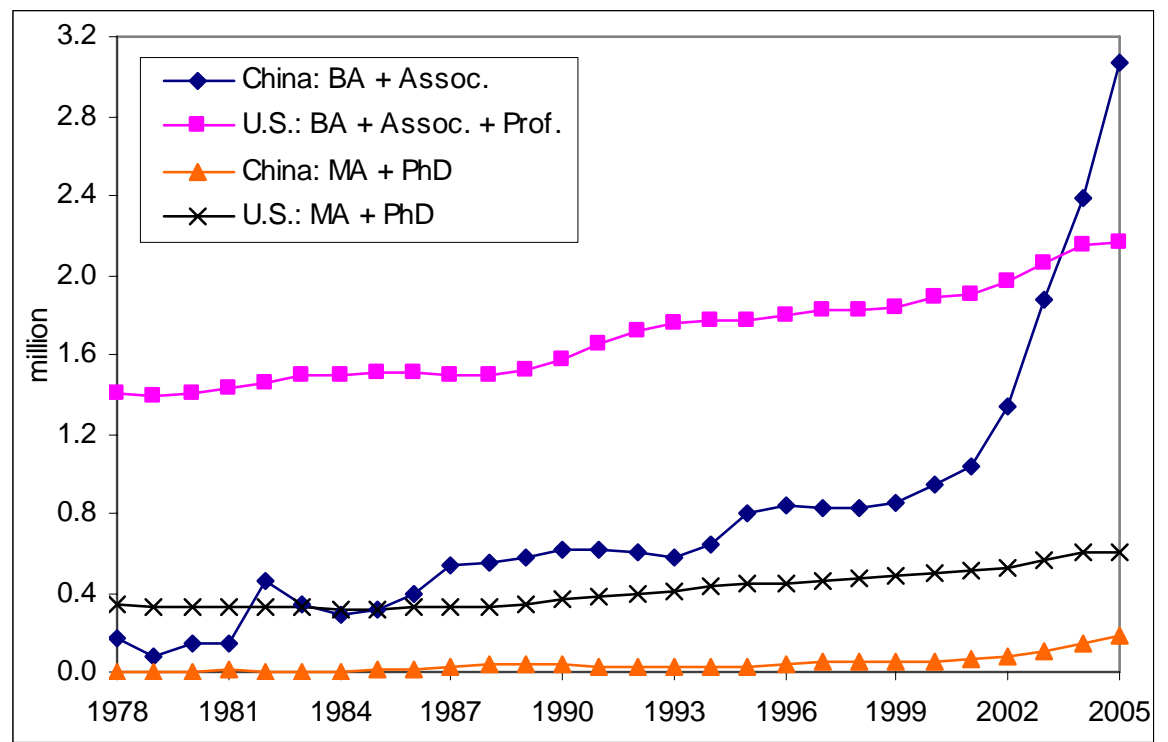

"BA" in the case of China refers to graduates of regular institutions of higher education, i.e., includes BA and college-level associate degrees granted by regular institutions of higher education; no data on college-level associate degrees granted by "non-regular" institutions of higher education are available. "BA" in the case of the U.S. refers to associate degrees, BA degrees, and first professional degrees. If first professional degrees had been included with MA/PhD, in 2005 the U.S. "BA" category would have been (projected to be) smaller by $3.92 \%$, and the U.S. MA/PhD category would have been larger by $13.95 \%$.

U.S. data for 2005 are official projections. Data for the U.S. for the years through 1995 cover "institutions of higher education," and since 1996 "degree-granting institutions." (Also see notes to Figure 12.)

In China, in 2005, 47.78\% of the "BA + Assoc." graduates received a BA degree, the others a college-level associate degree. In the U.S., in 2005, BA degrees are projected to outnumber associate degrees 2:1 $(1,416,000$ vs. 668,000$)$.

Sources:

China: Statistical Yearbook 1990, pp. 708f.; 2003, pp. 720f.; 2004, pp. 780-2; 2005, p. 693.; 2006, pp. 798,801 .

U.S.: http://nces.ed.gov/programs/digest/d05/tables/dt05_246.asp, accessed on 15 Nov. 2006.

\section{Figure 13. Tertiary Level Graduates, China and U.S.}




\section{Notes}

1 Emma Broomfield (2003) provides an overview over the "China threat" literature. Stanley Lubman (2004) documents the negative views of China in U.S. congressional debates.

2 The quotes are from "The China Price" in Business Week, 6 Dec. 2004 (issue 3911), pp. $102 \mathrm{ff}$.

Statistical Yearbook 2006, pp. 734, 1025.

See The Economist, 15 Nov. 2003, p. 67, quoting the Bank Credit Analyst, a Canadian research firm.

Since this paper was first written, Dwight Perkins and Thomas Rawski (2006) have embarked on a similar endeavor. They rely on the growth accounting equation derived from the Cobb-Douglas production function, using income shares rather than estimating the weights. Their labor calculations are similar to those made here; their future capital series are assumed series.

6 This paper is also not concerned about how meaningful the concept of GDP data is for measuring "wellbeing" or "standard of living." One may further question if value-added created in China contributes as much to well-being as does value-added created in the U.S., or vice-versa. Since the use of GDP as a measure of economic size, or, in per capita terms, as a proxy for standard of living, dominates in the literature as well as in popular discussions, this paper focuses on GDP.

See Statistical Yearbook 2006, pp. 57, 734; http://www.bea.gov/bea/newsrel/gdpnewsrelease.htm (accessed 30 Nov. 2006).

8 The GDP data are those published by National Bureau of Statistics in China (for China) and those published by the Bureau of Economic Analysis in the U.S. (for the U.S.). The PWT also include GDP values; in the case of China these incorporate manipulations of the official values in accordance with adjustments to official values suggested by Angus Maddison. Carsten Holz (2006a) argues that none of Angus Maddison's adjustments is justified (and questions Angus Maddison's [2006] reply in Carsten Holz [2006d]). The PWT GDP values for China are not used in the following, except in Figure 6.

The PWT 6.1 for the year 2000 (the most recent year covered in the PWT 6.1) report a factor of 4.32; in the PWT 6.2, for 2000, it is 4.22. This suggests a rather small margin of error, except that the PWT 6.2 values seem to incorporate very little new information.

10 In order to avoid lengthy footnotes, three technical issues are combined into one appendix with notes on the extrapolations: (i) the PWT derivation of the purchasing power parity factor; (ii) the combination of real growth and purchasing power parity; and (iii) the meaning of data on coastal China. This appendix, together with five further appendices, is available at http://ihome.ust.hk/ socholz. The other five appendices cover (i) data sources and explanations for Figure 1 through Figure 8, (ii) the results and implications of production function estimations, (iii) an explanation of labor data, (iv) a comparison of the U.S. vs. Chinese education system, and (v) a comparison of high school and tertiary level data of the U.S. and China.

11 In a different approach, Wing-Thye Woo (1999) examines the results of sector-level reforms in China, thus breaking down the case of China into several sectoral observations (which, however, are not independent). Thomas Rawski (1999) traces the interaction between different reforms; in total, these are taken to add up to the reform success. The World Bank (1997) examines a variety of "strengths and advantages" that it considers to promote economic growth, and a variety of "risks and challenges" that it considers to hamper economic growth (p. 19).

${ }_{12}$ Many constraints have disappeared after twenty-five years of reform. In terms of sales value, prices of approximately $90 \%$ of all goods have been liberalized. (See the Price Yearbook each year for the shares of prices that are market prices, mandatory prices, or guidance prices, for each of three categories: agricultural procurement, retail sales, and producer goods. It is questionable if "market prices" in China are truly market prices, and are so at all times.) State trading monopolies have largely disappeared. Export and import interventions (from administrative controls to quotas and tariffs/ subsidies) are all reaching the long-run levels committed to by China when joining the WTO. China has current account convertibility and partial capital account convertibility. Most sectors of China's economy are open to new entry by enterprises in all ownership forms; in industry, for which detailed data are available, only $35 \%$ of value-added in 2003 was produced by state-owned or state-controlled enterprises. (Statistical Yearbook 2004, pp. 53, 518.) Other constraints remain, from ownership restrictions in the banking system to the appointment mechanisms in state-owned enterprises and the prohibition of land sales among farmers.

13 The first two are standard fare in development economics; see, for example, James Cypher and James Dietz (1997), pp. 27ff., 267, 403. The third is a basic theorem in trade theory as a corollary of the Heckscher-Ohlin theorem; see, for example, Dominick Salvatore (1998), Chapter 5. No attempt is made to control for the varying degrees to which these patterns might apply to a specific country at a given point of time (with variations in degree due to, for example, policy constraints).

14 Other East- or South-East Asian nations could have been included. The Philippines, in particular, would have been an interesting case due to the generally poor economic growth performance (significantly different values of the dependent variable than in the other four countries). But including the Philippines would have meant controlling for religion, and perhaps also for climate and ownership structure. This would imply gaining one degree of freedom (one extra observation, the Philippines), while at the same time losing between one and 
three degrees of freedom due to the new control variable(s), with no overall gain, if not a loss, of explanatory power. Singapore or Hong Kong would have required a city-state control variable, and perhaps a second control variable to account for the fact that Hong Kong since 1997 is part of China. Thailand and Malaysia would probably have confirmed the patterns observed for Korea and Taiwan. India may have needed a separate control variable for colonial history. Going further afield would have meant the necessity for more control variables, but the absence of data on one control variable, even if in one country only, would then have brought about the loss of this control variable, causing omitted variable bias.

15 See note 10 for the web location of the appendix.

16 Employment data for China experience a statistical break between 1989 and 1990 when total employment, following the 1990 population census, increases by $17.03 \%$. In the following, total employment data for the years prior to 1990 are adjusted; for details, see Carsten Holz (2006e). Primary sector data, and the share of the primary sector in total employment are the official values at all times.

17 While doubts are occasionally raised about the accuracy of the data on the number of laborers in agriculture, suggesting that the official data constitute an over-count, the 1996 agricultural census (with a distinction between pure farmers and part-time farmers) as well as the 1990 and 2000 population censuses (with unambiguous definitions that should lead to a proper counting of migrant laborers) imply that the official primary sector labor data used here are, if anything, an underestimate.

18 In the case of the "structural change" pattern, the direction of causality is ambiguous in that one could argue for labor productivity growth to cause structural change. A clearer argument would be for labor productivity growth in non-agriculture that is different than labor productivity growth in agriculture to cause structural change; in the case here of economy-wide labor productivity growth the sign of the causality to structural change is ambiguous. At any rate, independent of the direction of causality, the charts presented here show that there is scope for the pattern to continue to unfold. One could, however, also argue that structural change is prior to economy-wide labor productivity growth in that shifts in labor allocation are happening in response to a relaxation of constraints to such shifts. Three constraints are limits on rural land markets, the two-class household registration system, and farming as a way of life; in all three respects, government decisions on liberalization and change have led (and continue to lead) to a gradual relaxation. (Also see Carsten Holz, 2006c.) 19 This leaves unaddressed the question of how much catching up is feasible for a given country at a given time. Moses Abramovitz (1986) elaborates on the "social capability" to catch up and on the factors controlling the rate of realization of the potential for catching up (facilities for the diffusion of knowledge, conditions facilitating or hindering structural change, and macroeconomic and monetary conditions).

20 A second-degree polynomial is imposed on the trend lines in Figure 4 and in the following figures. In contrast, a linear trend was used in Figure 2 because one extreme outlier in the case of Taiwan as well as in the case of Japan would have resulted in (highly misleading) sharp inverse-U shaped curves for these two countries. 21 See note 8.

22 If the scope for catching up were measured by the labor productivity differences in the industrial sector only (rather than economy-wide), China's highest level of catching up would probably be slightly higher, but not yet in the range where the corresponding growth rates of real GDP per laborer fall off significantly.

23 These assumptions are: two countries; two commodities (goods); two factors of production; same, constant returns to scale technology in use in both countries; across both countries one commodity is labor intensive, the other capital intensive; incomplete specialization in production in both countries; tastes are equal in both countries; perfect competition in both goods and factor markets in both countries; perfect labor mobility within each country but no international factor mobility; no transportation costs, tariffs, or other obstructions to the free flow of international trade; all resources are fully employed in both countries; international trade between the two countries is balanced. (Dominick Salvatore, 1998, p. 110.)

24 The factor price equalization theorem would also appear to provide the basis of the "comparative-advantage following strategy" argued for by Justin Lin, Cai Fang, and Li Zhou (2003)

25 A chart with annual wages relative to the U.S., based on the absolute factor price equalization theorem, is very similar to Figure 4 (with GDP per laborer as a measure of catching up) and omitted; this is due to the fact that labor shares in GDP tend to be constant over time and similar across countries. (Wages are obtained by dividing the labor remuneration component of GDP by the number of laborers.)

26 Robert Barro and Xavier Sala-i-Martin (1995, p. 352) stress that "growth accounting does not ... constitute a theory of economic growth because it does not attempt to explain how the changes in inputs and the improvements in total factor productivity relate to elements - such as aspects of preferences, technology, and government policies - that can reasonably be viewed as fundamentals." Even if such relationships could be specified, the next question that arises is what explains preferences, technology, and government policies? Trying to trace economic growth back to original causes presents a problem of infinite regress. The decision on when to stop, i.e., which level to view as ultimate "explanation," appears arbitrary.

27 The same holds for the most recent draft analysis of past and future growth by Dwight Perkins and Thomas Rawski (2006).

${ }_{28}$ For the results of production function estimations with the data used here see an appendix. 
29 Provincial gross value-added in the income approach in most years, for most provinces, exactly equals provincial gross value-added in the production approach, China's official approach to calculating GDP. But the sum of provincial gross value-added only closely, not perfectly matches China's national GDP value; the NBS does not solely rely on the provincial data when deriving the national GDP value. In addition, a very few provinces do not report income components for some of the early reform years. As long as the discrepancy between sum provincial GDP and national GDP does not reflect a particular bias in the size of one or more of the different income components (and there is no reason why it should), the procedure used here yields accurate national income component values. The provincial data are from GDP 1952-95 for the years 1978-1995, and from GDP 1996-2002 for the years 1996-2002; since the mid-1990s, each issue of the annual Statistical Yearbook also reports the data of the previous year.

30 Business profit equals profit net of investment returns and non-business revenues. For details on the link between the operating surplus and profit (or business profit) see Carsten Holz (2003), pp. 88f. The definition of operating surplus in China follows the standard System of National Accounts promulgated by the United Nations. Individual-owned enterprises with seven or fewer employees (getihu) by definition do not have any operating surplus; their operating surplus is subsumed in labor remuneration. In as far as the individual-owned economy grows over time relative to other ownership forms, operating surplus as a share of GDP is likely to fall. 31 Arnold Harberger (1998, p. 1) postulates a growth equation that attributes "to each factor a marginal product measured by its economic reward" in form of $\bar{p} \Delta y=\bar{w} \Delta L+(\bar{\rho}+\delta) \Delta K+R$, with the variables denoting initial general price level, change in output (GDP), initial real wage, change in labor input, initial real rate of return to capital, rate of real depreciation of capital, change in capital stock, and the residual interpreted as "real cost reduction." Compared to the definitional identity of the income growth accounting equation (and incorporating the price level in the coefficients of capital rather than in capital), the real cost reduction in his postulated equation, once divided by output, is identical to the weighted growth rates of real wages, the real depreciation rate, the real rate of return, and a particular form of change in the rate of net taxes on production. 32 Since the right-hand side variables are deflated using the implicit GDP deflator as first published, real growth rates of GDP are also based on this deflator. GDP based on the official real growth rates (which are usually not revised, while nominal data are), grew by $759 \%$.

33 Annual data on laborers by age and education for the period 1978-2003 are obtained / calculated from the 1982, 1990, and 2000 population censuses together with the 1987 and $19951 \%$ population sample surveys. Projections for the years 2000-2025 make use of year 2000 census data and past patterns and trends. An appendix on labor data provides slightly more explanations on the derivation of the labor data; all calculations and estimations are explained in Carsten Holz (2005).

34 Alwyn Young (2003), for example, regresses individuals' wages on gender, age (for which he has a total of 11 categories), and education (total of 4 categories).

35 The likelihood ratio statistics with a small-sample multiplication factor of T-c (T numbers of observations, c numbers of restrictions) as well as the Schwartz Information Criterion were used to determine when to stop reducing the number of lags. The number of observations was held constant across all lag lengths, but because the number of observations is so small (annual data for the years 1978-2002), alternatively, the values of the decision criteria were also calculated for the maximum number of observations at each lag length, and a multiplication factor of $T$ was also used as an alternative with the likelihood ratio statistic. As a result of the different criteria, often more than one lag length appeared plausible. In that case, all relevant lag lengths were taken to the next step of cointegration testing.

36 The $\mathrm{R}^{2}$ values of the individual VEC equations all tend to be in the 0.8 and 0.9 range. Apart from the results reported in the table, many cointegration equations have insignificant coefficients, some cointegration equations have highly implausible coefficient values (and then always a comparatively poor fit when contrasted to the actual real wage rate series in a chart), and a very few, with significant and plausible coefficients, yield similar results as those reported in the table. The ones reported in the table have the best fit in a visual comparison of the actual and fitted values.

37 A different cointegration equation involving the share of laborers with primary school education rather than the share of laborers with upper middle school education exhibits strong Granger causality from both education variables to the wage series. The share of laborers with primary school education also has a negative coefficient. In a visual comparison of the actual wage series and these two fitted series, the fitted series reported in the table with the share of laborers with upper middle school education better matched the actual series.

38 Similarly, the largest share of the forecast error variance of the share of laborers with upper middle school education is due to its own shocks, but $60 \%$ of the forecast error variance of the share of laborers with college level education or above is explained by variation in the share of laborers with upper middle school education. The forecast error variance decomposition depends, in this particular instance, much on the Cholesky ordering of the variables. Reversing the order, $63 \%$ of the variance of the wage is explained by variation in the share of laborers at upper middle school.

39 Non-education variables are typically not cointegrated with the wage rate. Age, or age squared, does not have a unit root. The difference in the choice of variables for the cointegration equations in levels vs. in 
logarithms is necessitated by the fact that some variables have unit roots when the variable is measured in levels, but not when it is measured in logarithms, and vice-versa. For example, in levels, 'average years of schooling minus five' is not $\mathrm{I}(1)$ but $\mathrm{I}(2)$, while the share of laborers with college level education or above in logarithms is $\mathrm{I}(2)$. Average years of schooling is I(2) independent of if the variable is in levels or in logarithms.

40 The labor share in GDP (not net of taxes) has been near-constant throughout the reform period, with a mean of 0.5210 and a standard deviation of 0.0111 in 1978-2002, i.e., the coefficient of variation is only $2 \%$.

41 The U.S. and Chinese education systems are not perfectly comparable. An appendix establishes the equivalence of different degrees in the two countries. Three main complications are the following. First, the Chinese special middle-school degree is at least equivalent to the U.S. high school degree, but possibly in some circumstances even to the U.S. post-high school associate degree. Second, while the U.S. and China have comparable BA degrees, the Chinese MA degree differs from the U.S. MA degree in that the Chinese MA degree is a three-year post-BA research (thesis) degree rather than a one- to two-year predominantly taught degree; the Chinese $\mathrm{PhD}$ differs from the U.S. $\mathrm{PhD}$ in that it requires a prior MA and in that it is usually obtained in three years' time, compared to longer average study times for the U.S. PhD. Third, Chinese professional degrees are usually obtained in form of a BA, but may also take the form of an MA or PhD. 42 The educational level of the age cohorts in the late 40 s may be exaggerated in that some upper middle school graduates in China during the Cultural Revolution may have enjoyed no more than a lower middle school education under the label of an upper middle school education.

43 The actual 2006 figure has not yet been published. The 5\% increase is reported in a news item in China Infobank (http://www.chinainfobank.com) of 26 May 2006, titled "2006 nian zhongguo gaoxiao de zhaosheng guimo zai qunian 504 wan ren de jichushang zai zengjia 5\%” (The 2006 tertiary level new enrollment figure is $5 \%$ higher than last year's basis of $5.04 \mathrm{~m}$ ).

44 This assumes a narrow definition of undergraduate level graduates in China and a broad definition for the case of the U.S. In the case of China, the data comprise college-level associate degrees and BA degrees of regular institutions of higher education, i.e., omit associate degrees issued by non-regular institutions of higher education. In the case of the U.S., the data comprise associate degrees, BA degrees, and first professional degrees. In China, the number of (typically 3-year) college-level associate degrees and the number of BA degrees are approximately equal. In the U.S., the second outnumber the first (in the U.S. 2-year programs) two to one. (Also see notes to Figure 12 and Figure 13.)

45 If U.S. graduates with a first professional degree are included with the U.S. figure of MA and PhD recipients, the comparison with China is slightly further in favor of the U.S. But with Chinese medical doctors and lawyers primarily holding a BA degree (in the medical doctor's case a 5-year BA program), it seems inappropriate to include graduates of medical and law schools in the U.S. number but not in the Chinese number. ${ }_{46}$ These data ignore Chinese students studying abroad because no specific degree and program completion data are available on these. Assuming Chinese students abroad were all studying in MA and PhD programs, their number in 2002 was equivalent to approximately half of year 2005 domestic MA and PhD graduates; the 2005 number of returning students, after completed studies, was one-fifth the 2005 number of domestic MA and $\mathrm{PhD}$ graduates. (The data sources are the same as those listed with Figure 12.)

47 For details see an appendix (which also reports additional tertiary level data).

48 The head count comparison is furthermore likely to be incomplete, since education in China outside the regular institutions of higher education has not been taken into consideration, while the U.S. data make no distinction between "official" and "unofficial" education. For example, adult education outside the regular university system in China is not included in the tertiary education data presented. In 2001, 316,367 persons graduated with a degree from a tertiary level adult education institution. This number corresponds to just below $1 \%$ of the population age 25-40 on 1 November 2000. (Census 2000, Vol. 1, pp. 215-7; Education Yearbook 2002, p. 107)

49 There is little doubt that the Chinese education system is indeed capable of identifying the brightest children, with lower middle school to university admission now routinely based on entrance examinations. James Heckman (2005) expresses concern about financial hurdles for children from low-income families.

50 Given the demographics, why has China not "overtaken" the U.S. a long time ago? The immediate answer is China's choice of economic system prior to 1978. With uniform wages and access to higher-level education severely limited, neither were incentives for human capital accumulation in place nor the opportunities available. For example, tertiary level education almost ceased during the Cultural Revolution. In 1971, a since 1949 low of 600 students are reported to have graduated from a regular institution of higher education, down from 186,000 in 1965; only by 1977 did the figure again reach the 1965 level, with 194,000 graduates. (Statistical Yearbook 1990, p. 709.) This means that among the older generations, only the generation born in or before the 1940s had some access to tertiary level education.

51 Carsten Holz (2003), Chapter 8, provides some evidence on the price wars of the late 1990s among stateowned enterprises. Another demographic effect is that China's large pool of laborers, compared to other countries, could in time lead to a highly efficient allocation of labor in that each labor market niche can be filled by the appropriate talent. 
52 See Statistical Yearbook 2001, p. 80 (Balance of Payments), 2003, p. 67 (GDP), p. 654 (exchange rate). In France it was $28.56 \%$, in Germany $33.38 \%$, in the UK $28.07 \%$, and in the relatively small South Korea $40.82 \%$. Data for all countries except China are from the IFS. The value of China's exports of goods and services is not reported in the IFS, only the net export value, i.e., the difference of exports and imports of goods and services. The data on net exports and GDP for China in the IFS are virtually identical to those reported in China's national income accounts in the Statistical Yearbook series.

53 See Statistical Yearbook 2006, pp. 57, 76, 734. The shares of France, Germany, the UK, and Korea (from the IFS) are $26.10 \%, 40.12 \%, 26.32 \%$, and $42.50 \%$.

54 China in 2004 accounted for approximately $5 \%$ of world imports of oil, compared to the U.S. with $25 \%$ and Japan with 10\%. Caijing, no. 169 (2 Oct. 2006), p. 83.

55 China is also pursuing efforts to reduce energy use. The current Five-Year Plan (for 2006-10) stipulates an obligatory reduction of energy use per unit of GDP by $20 \%$ (over the five years). Energy reduction targets are also written into cadres' evaluation system.

56 For the data see Statistical Yearbook 2006, pp. 740-3.

57 Statistical Yearbook 2006, p. 505. These data are from the economic census 2004. Value added data for 2004 are not available. The data for 2005 do not come with an ownership breakdown; in 2005, industrial enterprises with annual sales revenue in excess of 5m yuan RMB accounted for $93.86 \%$ of total industrial value added (pp. 57, 511). Based on pre-economic census (unrevised) values, foreign-funded enterprises plus Hong Kong / Macao / Taiwan enterprises together in 2005 accounted for $28.57 \%$ of the value added produced in industrial enterprises with annual sales revenue in excess of 5m yuan RMB (Statistical Abstract 2006, p. 133). 58 Statistical Yearbook 2006, pp. 734, 751. Foreign-funded plus Hong Kong / Macao / Taiwan enterprises accounted for $70.84 \%$ of total exports by industrial enterprises with annual sales revenue in excess of $5 \mathrm{~m}$ yuan RMB in 2005 (Statistical Abstract 2006, p. 133).

59 Some early examples are Western internet-related firms, such as Yahoo and Google, bowing to Chinese Communist Party censorship, or Western firms selling internet filters and specially configured (Cisco) routers to the Chinese government. Also see Ronald Deibert (2006).

60 The currently most pressing issue is possibly environmental pollution. After many years of dithering and of condoning local disregard for environmental regulations, the current Five-Year Plan (2006-10) lists obligatory targets to reduce the use of water (per unit of value added by 30\%) and the volume of effluents (overall reduction by $10 \%$, with specific targets to be set by the State Environmental Protection Administration). 61 Qi Yuanjun (2005) presents an overview of progress towards the calculation of green GDP for China. No economy-wide figure appears as yet available, but work by the NBS and China's National Environmental Protection Office has begun to put a framework for green GDP into place within 3-6 years. 